\title{
Microencapsulation for Functional Textile Coatings with Emphasis on Biodegradability-A Systematic Review
}

\author{
Bojana Boh Podgornik*, Stipana Šandrić (D) and Mateja Kert \\ Department for Textile, Graphic Arts and Design, Faculty of Natural Sciences and Engineering, \\ University of Ljubljana, Snežniška 5, SI-1000 Ljubljana, Slovenia; stipana.sandric@gmail.com (S.Š.); \\ mateja.kert@ntf.uni-lj.si (M.K.) \\ * Correspondence: bojana.boh@ntf.uni-lj.si
}

check for

updates

Citation: Boh Podgornik, B.; Šandrić, S.; Kert, M. Microencapsulation for Functional Textile Coatings with Emphasis on Biodegradability-A Systematic Review. Coatings 2021, 11, 1371. https://doi.org/10.3390/ coatings11111371

Received: 22 September 2021 Accepted: 5 November 2021 Published: 9 November 2021

Publisher's Note: MDPI stays neutral with regard to jurisdictional claims in published maps and institutional affiliations.

Copyright: (c) 2021 by the authors. Licensee MDPI, Basel, Switzerland. This article is an open access article distributed under the terms and conditions of the Creative Commons Attribution (CC BY) license (https:/ / creativecommons.org/licenses/by/ $4.0 /)$.

\begin{abstract}
The review provides an overview of research findings on microencapsulation for functional textile coatings. Methods for the preparation of microcapsules in textiles include in situ and interfacial polymerization, simple and complex coacervation, molecular inclusion and solvent evaporation from emulsions. Binders play a crucial role in coating formulations. Acrylic and polyurethane binders are commonly used in textile finishing, while organic acids and catalysts can be used for chemical grafting as crosslinkers between microcapsules and cotton fibres. Most of the conventional coating processes can be used for microcapsule-containing coatings, provided that the properties of the microcapsules are appropriate. There are standardised test methods available to evaluate the characteristics and washfastness of coated textiles. Among the functional textiles, the field of environmentally friendly biodegradable textiles with microcapsules is still at an early stage of development. So far, some physicochemical and physical microencapsulation methods using natural polymers or biodegradable synthetic polymers have been applied to produce environmentally friendly antimicrobial, anti-inflammatory or fragranced textiles. Standardised test methods for evaluating the biodegradability of textile materials are available. The stability of biodegradable microcapsules and the durability of coatings during the use and care of textiles still present several challenges that offer many opportunities for further research.
\end{abstract}

Keywords: microcapsules; coatings; functional textiles; biodegradability

\section{Motivation and Research Questions}

The aim of this article is to provide a systematic review of recent research in the field of functional textile coatings based on microcapsules, with a particular focus on the biodegradability of microcapsules and textile products. More specifically, the review aims to elucidate the following questions: What are the trends in research publications on microcapsules for functional textiles? What are the purposes, effects and uses of microencapsulation in functional textile coatings? Which of the microencapsulation methods are suitable for applications in functional textiles, for which active ingredients and shell materials? Which application techniques are used on textiles, with which binders, catalysts, and pre-treatments of textiles? What is the stability of microcapsules during formation, application, and textile care, and what standardized testing methods are available? What proportion of research is focused on biodegradable microcapsules applied to biodegradable textiles? Which microencapsulation methods and materials are used in such products? Are the biodegradable microcapsules and formulations sufficiently stable for application and use on functional textile coatings? To our knowledge, these aspects have not yet been covered and presented in the review articles to date.

\section{Publication Trends in Microencapsulation for Textiles}

Industrial applications of microencapsulation were first introduced by the National Cash Register Company in the late 1950s for the encapsulation of leuco dyes in the man- 
ufacture of carbonless copying paper [1-3]. Since then, microencapsulation has been continuously improved and adapted for a variety of applications and functional effects. In addition to the printing industry on paper, microcapsules have also been used for textiles, pharmaceutical and medical purposes, in cosmetics and food products, agricultural formulations, and in the chemical, biotechnology, photography, electronics, building materials and waste treatment industries [4-9].

The first ideas for the specific use of microcapsules in textile products were born about five decades ago and soon developed into an important research field, not only with the growth of scientific publications, but also with pronounced protection of industrial intellectual property rights. As a result, the number of patent applications significantly exceeded the number of scientific articles (Figure 1), with China, Turkey and India being the leading countries of origin for scientific articles, and Japan, USA and China being the top countries of origin for patents (Figure 2).

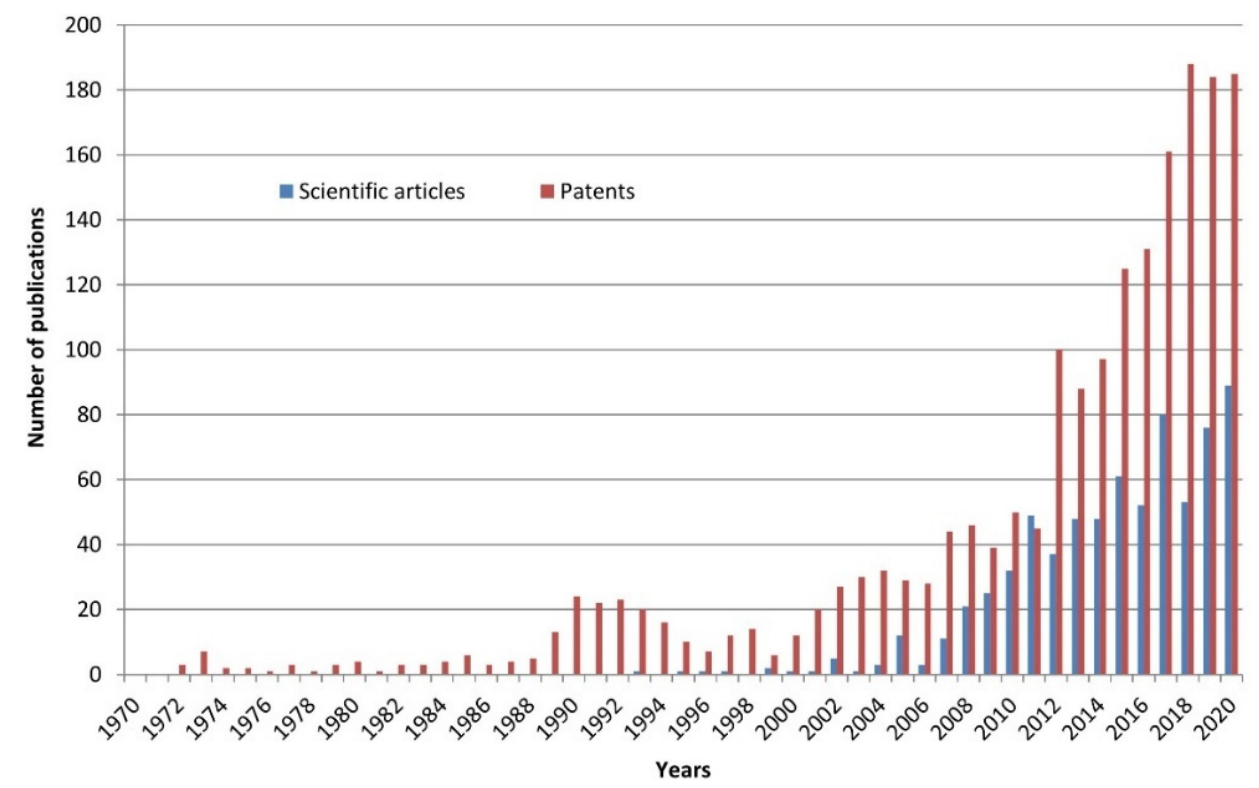

Figure 1. Trends in the number of new scientific articles in the Web of Science database [10] and patent documents in the Espacenet database [11] on microencapsulation for textiles. Search query: (microcapsule* OR microencapsulat*) AND (textile* OR cloth OR fabric OR garment*).

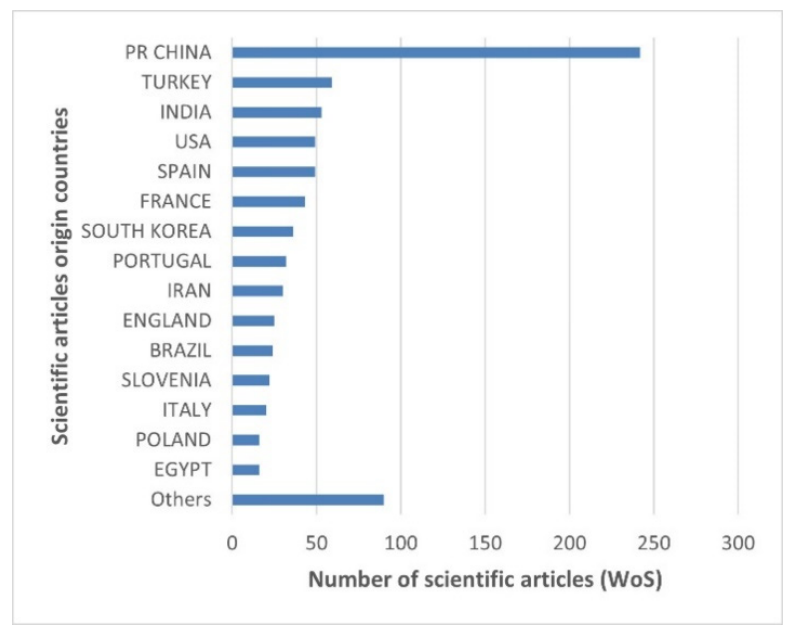

(a)

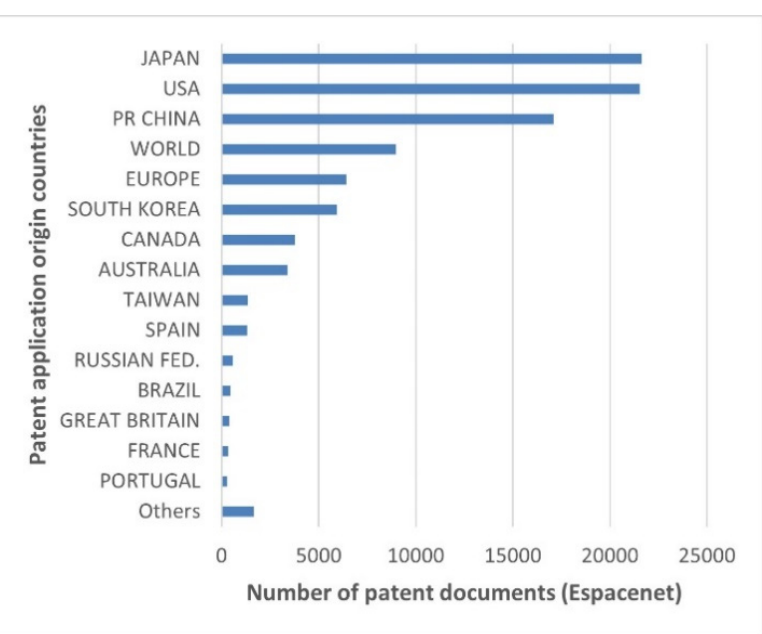

(b)

Figure 2. Origin countries of scientific articles in the Web of Science database (a) [10] and patent documents in the Espacenet database (b) [11] on microencapsulation for textiles. Search profile: (microcapsule* OR microencapsulat ${ }^{*}$ ) AND (textile* OR cloth OR fabric OR garment*); analysis by country. 


\section{Microcapsules in Functional Textile Products}

In the manufacture of textiles, garments and apparel, microencapsulation offers many opportunities to improve properties or provide entirely new functionalities, leading to broader usability and higher market value of the products. Scientific and patent literature reviews on microencapsulation applications in textiles have already been published [12-18]. In this paper, we aim to analyse recent scientific articles and highlight examples of research results in the field of functional textiles with microcapsules, as summarized in Figure 3, with a particular focus on the biodegradability of the final products.

\section{Microcapsules in functional textiles}

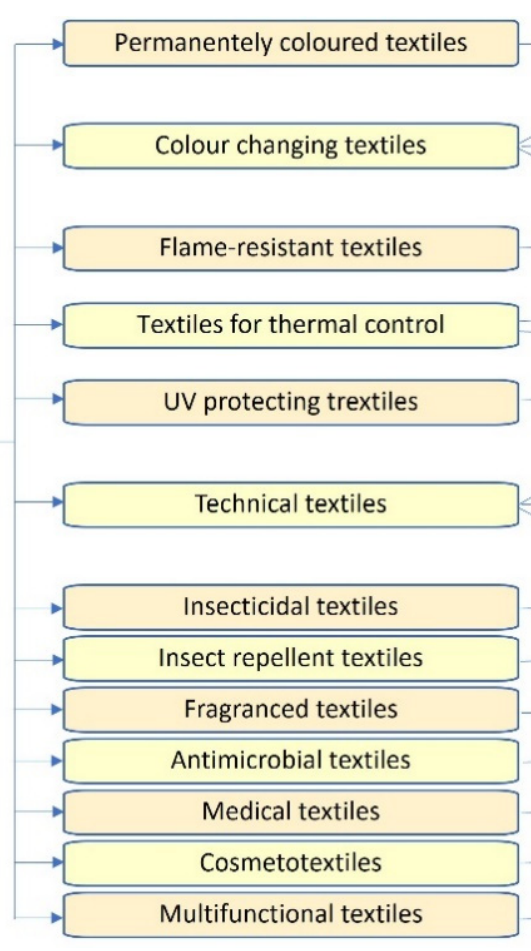

Figure 3. Functional textiles based on microencapsulated actives.

One of the initial microencapsulation applications to achieve innovative effects in textile processing have been microencapsulated dyes and pigments for special textile printing and dyeing. Varieties of these include microencapsulated colorants for permanent dyeing and printing of textiles [19-21], as well as colour changing textiles based on thermochromic microcapsules [22-25], photochromic dyes [26-29], and electrochromic textiles containing microencapsulated liquid crystals [30-32].

To achieve durable flame-resistance of textiles, organic or inorganic fire retardants have been microencapsulated and applied to textile substrates. Microencapsulation has been used to prevent exudation or sublimation of fire-retardant chemicals, to avoid reactions with textile polymers, and/or to overcome the hydrophilicity of the substances. Products include firefighting and military protective clothing, as well as textiles for automotive and domestic interiors [33-36].

One of the flourishing applications of microencapsulation is functional textiles for active thermoregulation, used in insulating textiles, technical clothing, and sportswear. Most textiles for thermal regulation use phase change materials (PCMs), in which a dynamic heat exchange process occurs at the melting point temperature. To overcome the practical problems of solid-liquid phase transitions, PCMs must be microencapsulated and converted into solid formulations. When a PCM undergoes a solid-to-liquid phase transition, energy is stored in the form of latent heat at a constant temperature. The accumulated latent heat energy is released when the PCM re-solidifies, and the transition process is reversible. Typical organic PCMs are paraffin hydrocarbons or lipids with a melting point close to body temperature [37-46]. In addition to classical PCMs, photothermal energy conversion 
materials also perform similar functionalities. By absorbing light and converting it into thermal energy, they are used in light-absorbing thermoregulatory textiles [47-49].

To prevent UV-induced skin problems, some authors have incorporated microencapsulated synthetic or natural UV-absorbing compounds into functional UV-protective fabrics [50-52].

In other technical textiles, microencapsulation has been used to achieve specific functionalities, such as improved sound absorption [53], superhydrophobicity [54], antifouling [55] and enzymatic bio-sensing [56].

Microencapsulated insecticides [57], acaricides [58], insect repellents [59,60] and combined bioinsecticide-insect repellent compounds [61,62] have been used in textiles to reduce volatility, prolong release and decrease washfastness of active compounds from textile substrates.

Fragranced textiles often contain essential oils, perfumes, or aromas in microencapsulated form to either gradually release the active ingredients through permeable shells, or to protect the cores inside the impermeable microcapsules until they are released by mechanical pressure or rubbing during product use. Modifications of the shell materials and binding formulations play an essential role in achieving better washing resistance over multiple washing cycles and in prolonging olfactory sensations [63-68].

Some aromatic compounds, such as essential oils and their components, not only provide a pleasant fragrance effect but also offer antimicrobial protection [69]. Being liquid, volatile and susceptible to oxidation, microencapsulation is required for their protection and conversion to solid state. The release mechanisms vary from slow diffusion through the permeable shell to instantaneous release triggered by pressure or melting. Antimicrobial textile products include hygiene masks, footwear, sportswear, medical garments and biofunctional materials [70-75].

Bioactive healthcare textiles have similar functionalities. Microcapsules must be composed of natural and biocompatible materials and approved for direct skin contact. Examples of medical textiles include microencapsulated antibiotics [76], methyl salicylate [77], cannabidiol [78], ozonated vegetable oils [79], lime oil [80] and chitosan [81]. Microcapsules for cosmetotextiles [82] contain skin-caring active ingredients, such as essential oils and vitamins [83-85].

Functional textiles initially focused only on individual value-adding properties. However, recent research has targeted combinations of multiple properties and effects, leading to new multifunctional smart textiles with three or more functionalities in one product, such as simultaneous aromatic, antimicrobial, UV-protective and superhydrophobic effects [86-89].

\section{Purposes and Effects of Microencapsulation in Functional Textiles}

Not all functional textiles need to contain microcapsules. Microencapsulation has been used as a means to impart finishes and properties to textiles that were not possible or cost effective with other technologies [18]. Therefore, microencapsulation can be used beneficially in functional textile products for the three main groups of purposes and effects [14,15,45,68,69] (Figure 4):

- Permanent protection or separation of a core material for the life of the product. Such long-life microcapsules provide localized activity by permanently confining the liquid core within the mechanically resistant shell, as in PCMs for active thermal regulation or colour-changing textiles with electrochromic, photochromic and thermochromic materials.

- Targeted release of the core under planned conditions that trigger the opening of the shell. When temporary isolation and rapid, targeted release of active components from the core is envisaged, microcapsules with impermeable shells burst open by mechanical pressure, abrasion, melting or thermal decomposition. Until release, the active components in the microcapsule core remain separated from the reactive components (leuco dyes and colour developers), converted from a liquid to a solid state 
and protected against evaporation (essential oils) or protected against environmental influences and oxidation (essential oils, lipids and vitamins).

- Long-lasting, gradual release by diffusion through the permeable microcapsule shell. This principle is used in long-lasting perfumed textiles, in insect repellent fabrics and in sustained-release medical and cosmetic textiles.

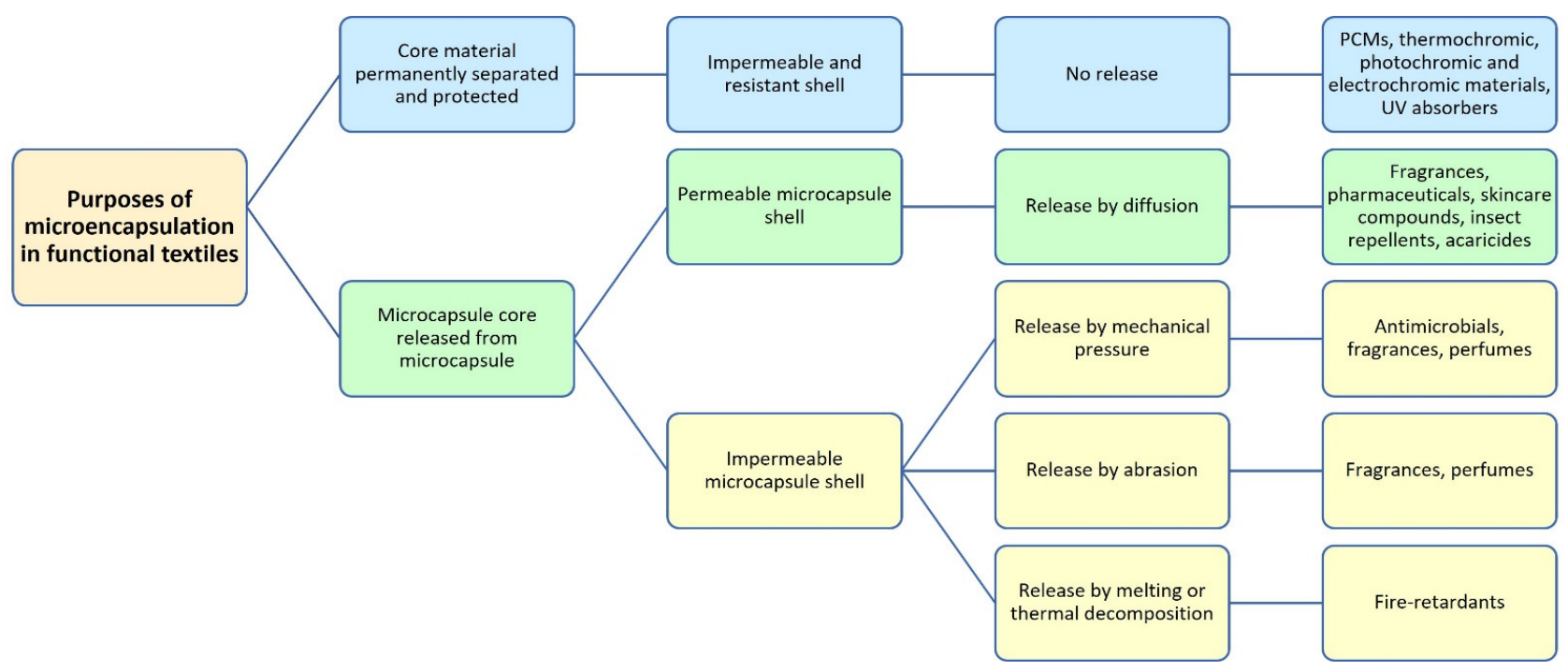

Figure 4. Main purposes for the use of microcapsules in functional textiles, in terms of shell permeability, release mechanisms and active ingredients.

\section{Microencapsulation Methods for Functional Textiles}

During the evolution of microencapsulation technologies, a wide range of possible processes and techniques have been developed and modified to produce microcapsules with desired materials and target properties. Microcapsule size, morphology, shell and core materials, release mechanisms, compatibility with other components of the formulation, application technologies to textiles, environmental impact and biodegradability can be imaginatively defined and thoughtfully planned. Various authors of reviews in the field of microencapsulation have classified microencapsulation methods in different ways [81,90-95]. However, not all methods are applicable specifically to textile applications, and microcapsules have most commonly been produced using one of the methods shown in Figure 5, with examples analysed and specified in Sections 5.1-5.3.

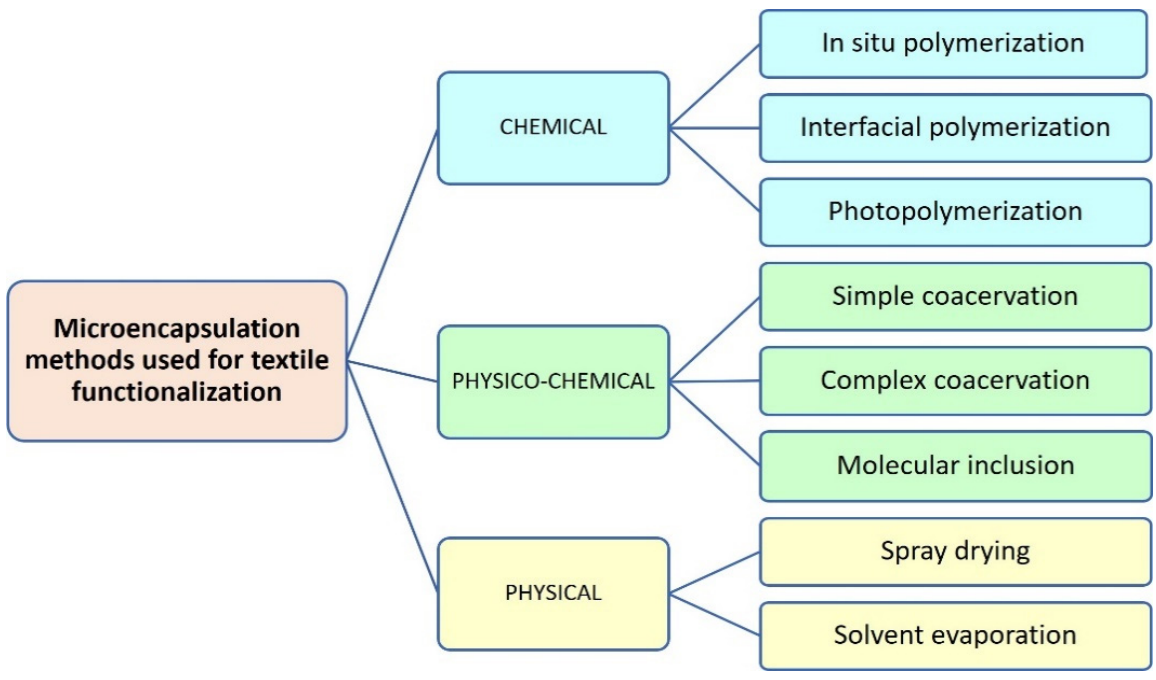

Figure 5. Microencapsulation methods commonly used in textile functionalization. 


\subsection{Chemical Microencapsulation Methods for Functional Textiles}

Chemical microencapsulation methods take place in emulsions and are based on the polymerization of monomers around emulsified core droplets to form a solid and durable polymer wall. Research examples of chemical microencapsulation methods used for textile functionalization are listed in Table 1. In situ polymerization of aminoaldehyde resins appears to be the most frequently used microencapsulation method for functional textiles, particularly to produce scented textiles, thermal protective clothing with PCMs, flame retardant textiles, photochromic fabrics and antimicrobial textile products. Interfacial polymerization has been used to prepare polyurea or polyurethane microcapsules for scented or perfumed textiles, while photopolymerization has been experimentally applied for multifunctional cotton textiles.

Table 1. Chemical microencapsulation methods for textile functionalization: overview of published examples.

\begin{tabular}{|c|c|c|c|}
\hline Shell Materials & Core Materials & Functional Textiles & Ref. No. \\
\hline \multicolumn{4}{|c|}{ In situ Polymerization Method } \\
\hline $\begin{array}{l}\text { Melamine-formaldehyde } \\
\text { polymer. }\end{array}$ & $\begin{array}{c}\text { Sage, rosemary and lavender } \\
\text { essential oils in isopropyl myristate. } \\
\text { Antimicrobial triclosan. Fire retardant } \\
\text { triphenyl phosphate. }\end{array}$ & $\begin{array}{l}\text { Cotton woven fabrics with } \\
\text { fragrant, antimicrobial, or } \\
\text { flame-retardant functionalisation. }\end{array}$ & [96] \\
\hline- & $\begin{array}{l}\text { Antifungal pharmaceutical } \\
\text { agent terbinafine. }\end{array}$ & Antifungal cotton fabrics. & [97] \\
\hline $\begin{array}{l}\text { from prepolymer, with Sodium } \\
\text { lauryl sulphate emulsifier. }\end{array}$ & PCM n-octadecane. & $\begin{array}{l}\text { Cellulose-polyester fabrics with } \\
\text { improved thermoregulation. }\end{array}$ & [98] \\
\hline $\begin{array}{l}\text { from partially methylated } \\
\text { trimethylolmelamine prepolymer, } \\
\text { with styrene maleic anhydride } \\
\text { copolymer modifier. }\end{array}$ & $\begin{array}{l}\text { Thermochromic PCM composition: } \\
\text { crystal violet lactone dye, bisphenol } \\
\text { A developer, tetradecanol solvent. }\end{array}$ & Thermal protective clothing. & [43] \\
\hline- & Paraffinic PCM Rubitherm ${ }^{\circledR} \mathrm{RT} 27$. & $\begin{array}{l}\text { Microcapsules incorporated in } \\
\text { melt spinning of polypropylene } \\
\text { textile fibres. }\end{array}$ & [99] \\
\hline- & Rose essential oil. & Fragranced textiles. & [100] \\
\hline $\begin{array}{l}\text { with polyacrylic } \\
\text { polymer modifier. }\end{array}$ & Male and female fragrance oils. & $\begin{array}{l}\text { Fragranced textiles-scented } \\
\text { bow-ties. }\end{array}$ & [101] \\
\hline- & $\begin{array}{l}\text { Lavender, rosemary and sage } \\
\text { essential oils. }\end{array}$ & Fragrant cotton textiles. & [102] \\
\hline $\begin{array}{l}\text { with sodium salt of styrene maleic } \\
\text { anhydride copolymer and sodium } \\
\text { polyacrylate modifiers. }\end{array}$ & Thermochromic PCM mixture. & $\begin{array}{l}\text { Non-woven functional } \\
\text { thermochromic textiles with } \\
\text { improved thermal regulation. }\end{array}$ & [48] \\
\hline $\begin{array}{l}\text { modified with multiwall carbon } \\
\text { nanotubes and poly } \\
\text { (3,4-ethylenedioxyoxy-thiophene) } \\
\text { poly (styrene sulphonate) }\end{array}$ & $\mathrm{PCM}$ paraffin with $\mathrm{MP} 30-32^{\circ} \mathrm{C}$. & $\begin{array}{l}\text { 3D warp-knitted spacer fabrics } \\
\text { from polyethylene terephthalate } \\
\text { (PET) and elastane, with } \\
\text { improved thermal properties. }\end{array}$ & [103] \\
\hline $\begin{array}{l}\text { Melamine-urea-formaldehyde } \\
\text { polymer from prepolymer. Tween } \\
20 \text { emulsifier. }\end{array}$ & Photochromic dyes in ethyl acetate. & $\begin{array}{l}\text { Cotton fabrics with reversible } \\
\text { photochromic response. }\end{array}$ & [104] \\
\hline \multicolumn{4}{|c|}{ Interfacial Polymerization Method } \\
\hline $\begin{array}{l}\text { Polyurea from hexamethylene } \\
\text { diisocyanate and guanidine } \\
\text { carbonate. } \mathrm{N}^{-\mathrm{TiO}_{2}} \text { particles } \\
\text { loaded on the shell surface. }\end{array}$ & Citral fragrance. & $\begin{array}{l}\text { Fragranced and photocatalytic } \\
\text { bifunctional cotton textiles for air } \\
\text { purification and personal protection. }\end{array}$ & [105] \\
\hline
\end{tabular}


Table 1. Cont.

\begin{tabular}{|c|c|c|c|}
\hline Shell Materials & Core Materials & Functional Textiles & Ref. No. \\
\hline $\begin{array}{l}\text { Polyurethane-urea polymer from } \\
\text { isocyanate/PEG- } 400 / \text { polyamine. }\end{array}$ & Methyl cedryl ketone fragrance. & $\begin{array}{c}\text { Fragranced cotton, Polyester and } \\
\text { silk textiles. }\end{array}$ & [63] \\
\hline $\begin{array}{c}\text { from hexamethylene diisocyanate, } \\
\text { polyethylene glycol, } \\
\text { thylenediamine, hydrazine. }\end{array}$ & Limonene oil. & Wool-polyester perfumed Textiles. & [106] \\
\hline $\begin{array}{c}\text { Bio-polyurethane composed of } \\
\beta \text {-cyclodextrin and } \\
4,4^{\prime} \text {-methylenebis(phenyl } \\
\text { isocyanate). }\end{array}$ & Neroline perfume. & $\begin{array}{l}\text { Perfumed polyamide } \\
\text { knitted textiles. }\end{array}$ & [107] \\
\hline \multicolumn{4}{|c|}{ Photopolymerization method } \\
\hline $\begin{array}{c}\text { Hexanediol diacrylate/ } \\
\text { modified } \mathrm{TiO}_{2} \text {. } \\
\text { Perfluorooctyltriethoxysilane and } \\
\text { UV absorber Tinuvin grafted on } \\
\mathrm{TiO}_{2} \text { nanoparticles. }\end{array}$ & Osmanthus fragrance oil. & $\begin{array}{l}\text { Multifunctional cotton textiles } \\
\text { with fragranced, } \\
\text { superhydrophobic and UV } \\
\text { protective properties. }\end{array}$ & [86] \\
\hline
\end{tabular}

\subsubsection{In Situ Polymerization Microencapsulation}

In situ polymerization takes place in oil-in-water emulsions, allowing the formation of microcapsules with hydrophobic core materials immiscible with water. The result is spherical, reservoir-like microcapsules with smooth, transparent, durable and pressuresensitive microcapsule shells (Figure 6).

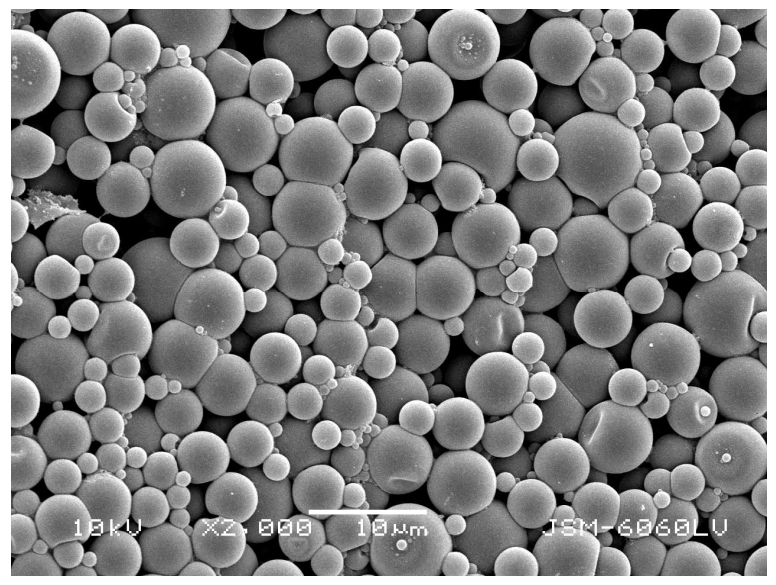

(a)

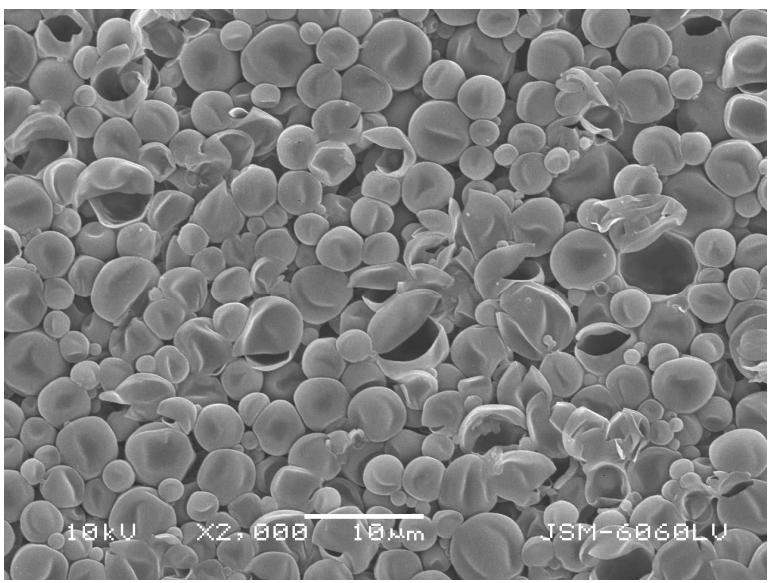

(b)

Figure 6. In situ polymerization microcapsules of citronella oil with melamine-formaldehyde shells: (a) intact microcapsules; (b) microcapsules after activation by pressure and partial core release (research archive, Boštjan Šumiga).

Typical shell materials for in situ polymerization are amine-aldehyde resins (aminoplasts), such as urea-formaldehyde, melamine-formaldehyde, urea-melamine-formaldehyde, or resorcinol-modified melamine-formaldehyde synthetic polymers. The synthesis processes can either start from monomers, such as urea and formaldehyde or melamine and formaldehyde, or from prepolymers, such as partially methylated trimethylolmelamine or hexamethoxymethylolmelamine, which are easier to control [108,109].

Since polymerization of all materials for the microcapsule shell occurs exclusively in the continuous water phase and on the side of the continuous phase at the interface formed by the dispersed core material and the continuous phase, all shell monomers or prepolymers must be water soluble. Polymerization initially produces prepolymers of relatively low molecular weight that remain soluble in the continuous phase, but as the molecular weight of the prepolymer increases, the polymers deposit on the surface of the 
dispersed cores in the emulsion. Polymerization continues at the surface of the droplets, and a solid shell is formed as crosslinking occurs. The separation and deposition process by which the microcapsule shell is formed largely determines the encapsulation efficiency and shell morphology and can be controlled by changing the $\mathrm{pH}$ and temperature, by the amine and aldehyde type and molar ratio and by the type and amount of emulsifier used [110].

Under ideal conditions, all of the shell material precipitates and distributes evenly over the surfaces of the hydrophobic cores in the emulsion. To achieve better process control and improved mechanical properties of the microcapsules, emulsifiers/modifiers must be added to initially improve emulsification and later ensure that polymerization develops only on the surface of the emulsified microcapsule cores and not throughout the whole aqueous phase [109]. Examples of such emulsifiers/modifiers include styrene-maleic anhydride polymer $[43,48,100,109]$ and polyacrylic acid [96].

Aminoaldehyde microcapsules have excellent technological properties, are durable and resistant to chemical and physical agents. However, they have two important disadvantages - poor environmental degradability and the release of formaldehyde. Hydrolytic degradation of ureaformaldehyde polymers leads to significant weakening of resin bonds and is a source of formaldehyde emissions [111,112]. This is also particularly problematic in textile applications, as the limits for maximum allowable formaldehyde concentrations in various products, including textiles, have been lowered in recent decades. To reduce the formaldehyde content, formaldehyde residues can be removed from the suspension of microcapsules at the end of the in situ process by adding scavengers such as urea, melamine, ammonia or ammonium chloride $[109,111,113,114]$.

\subsubsection{Interfacial Polymerization Microencapsulation}

In microencapsulation by interfacial polymerization, one of the monomers is dissolved in the aqueous phase and the other in an organic lipophilic solvent of the emulsion. Both monomers react at the droplet interface to form a polymer membrane- the microcapsule shell. The active core material can be oil-soluble or water-soluble, so the oil-in-water or water-in-oil type emulsion must be selected accordingly. Four main types of shell polymers have been developed and used in microencapsulation by interfacial polymerization, consisting of polyamides (reaction of diamines and diacid chlorides) (Figure 7), polyurethanes (reaction of diisocyanates with diols), polyureas (reaction of diamines with diisocyanates) and polyesters (reaction between diacid chlorides and diols). The formation of a polymer shell at an interface involves complex mechanisms that are not yet fully understood. The reaction begins at the liquid interface, and as the shell initially forms, the reaction site moves. As the oligomers in the dispersed droplet become largely insoluble, the polymer precipitates near to the interface and reservoir-type microcapsules form. A further comprehensive analysis of both the chemical and physical processes involved in microencapsulation by interfacial polymerization and the implications for membrane formation and structure was published in [115]. In microcapsules for textile applications, shells have been reported of polyurea [105], polyurethane urea [63,106] and bio-polyurethane [107].

\subsection{Physico-Chemical Microencapsulation Methods for Functional Textiles}

Physico-chemical microencapsulation methods for textile applications (Table 2) consist of simple and complex coacervation processes, and of molecular inclusion with cyclodextrins. Their important advantage is that environmentally friendly shell materials can be used, often of natural origin, that are safer for direct skin contact and textile degradation after use. However, the disadvantage is lower durability and resistance to physical and chemical agents in the processes of microcapsule application, washing and use of functional textiles. 


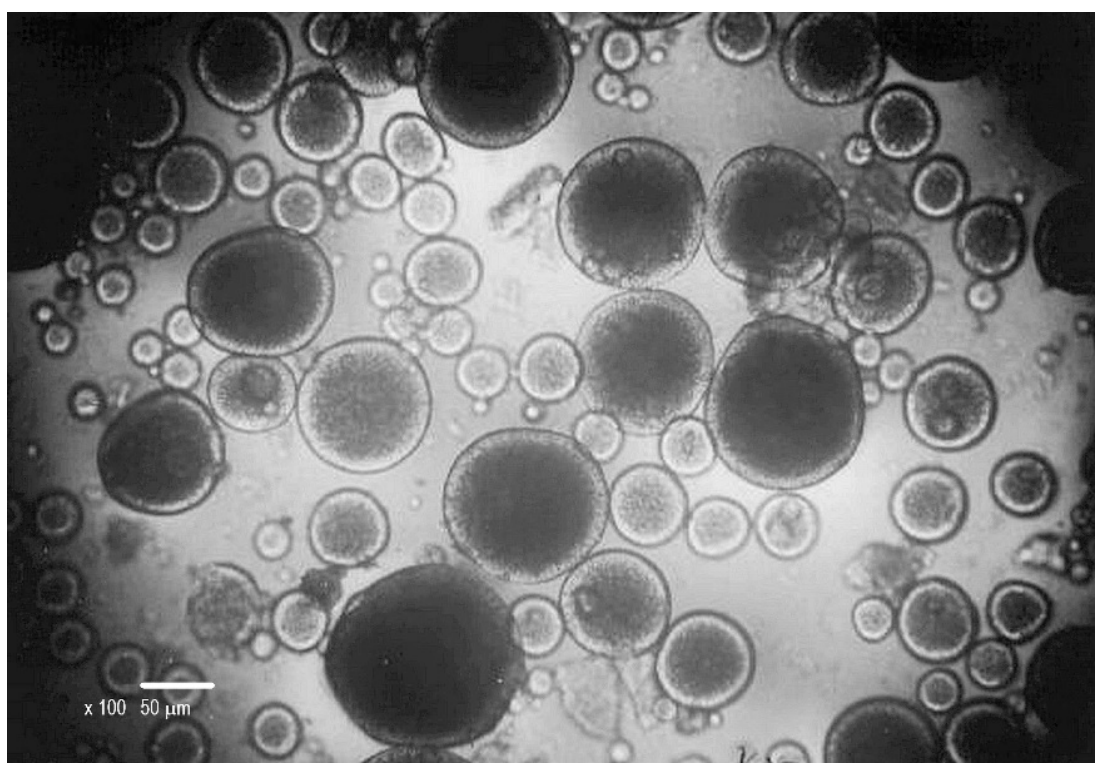

Figure 7. Polyamide shell microcapsules, prepared by interfacial polymerization in water-in-oil emulsion (transmission microscopy, 100×; authors' archive).

Table 2. Physico-chemical microencapsulation methods used for textile functionalization-examples of processes and materials.

\begin{tabular}{|c|c|c|c|}
\hline Shell Materials & Core Materials & Functional Textile & Ref. No. \\
\hline \multicolumn{4}{|c|}{ Simple Coacervation } \\
\hline Chitosan. & Cinnamon essential oil. & Antimicrobial woven cotton fabrics. & [70] \\
\hline Ethyl cellulose. & Photochromic dyes in ethyl acetate. & $\begin{array}{l}\text { Cotton fabrics with reversible } \\
\text { photochromic response. }\end{array}$ & [104] \\
\hline Corn starch, formaldehyde cross-linked. & Aloe vera oil. & $\begin{array}{l}\text { Cotton nonwoven bandages for } \\
\text { treatment of burned skin. }\end{array}$ & [116] \\
\hline Gum acacia, formaldehyde cross-linked. & $\begin{array}{l}\text { Eucalyptus oil and cedarwood oil as } \\
\text { insect repellent. }\end{array}$ & Insect repelling woven fabrics. & [117] \\
\hline \multicolumn{4}{|c|}{ Complex Coacervation } \\
\hline $\begin{array}{l}\text { Gelatin and gum Arabic, } \\
\text { glutaraldehyde cross-linked. }\end{array}$ & Citronella essential oil. & Mosquito repellent cotton fabrics. & [60] \\
\hline- & Methyl salicylate pharmaceutical. & $\begin{array}{l}\text { Cotton and polyamide Jersey knitted } \\
\text { pharmaceutical textiles. }\end{array}$ & [77] \\
\hline- & Propolis emulsion in rice oil. & Antimicrobial cotton textiles. & [118] \\
\hline $\begin{array}{l}\text { Chitosan-gum Arabic, } \\
\text { tannic acid cross-linked. }\end{array}$ & Limonene and vanillin. & Antibacterial cotton textiles. & [73] \\
\hline $\begin{array}{c}\text { Gelatine and sodium alginate, } \\
\text { glutaraldehyde cross-linked. } \\
\text { Hydrophilic bentonite nano-particles } \\
\text { doped on shell. }\end{array}$ & n-eicosane PCM. & $\begin{array}{l}\text { Cotton textiles with improved thermal } \\
\text { stability and flame-retardant properties. }\end{array}$ & [119] \\
\hline Silk fibroin andchitosan. & n-eicosane PCM. & Thermoregulated textiles. & [120] \\
\hline \multicolumn{4}{|c|}{ Molecular Inclusion } \\
\hline $\begin{array}{l}\text { Epichlorohydrin modified } \\
\beta \text {-cyclodextrin. }\end{array}$ & Indigo dye and lavender essential oil. & $\begin{array}{l}\text { Bifunctional coloured and fragranced } \\
\text { cotton textiles. }\end{array}$ & [121] \\
\hline$\beta$-cyclodextrin. & Citronella oil. & $\begin{array}{l}\text { Woven cotton and spun polyester } \\
\text { textiles with insect repellent activity. }\end{array}$ & [122] \\
\hline Hyper cross-linked $\beta$-cyclodextrins. & Melatonin sleep hormone. & Knitted cotton biofunctional fabrics. & [123] \\
\hline
\end{tabular}




\subsubsection{Coacervation}

Coacervation microencapsulation processes occur in colloidal systems in which macromolecular, colloid-rich coacervate droplets surround dispersed microcapsule cores and form viscous microcapsule shells that are solidified with crosslinking agents (Figures 8 and 9). In practice, water-insoluble actives are emulsified into the continuous aqueous phase containing a dissolved macromolecular colloid to form an oil-in-water emulsion. The coacervation process is induced by controlled modification of parameters such as $\mathrm{pH}$, ionic strength, temperature or solubility. Shell formation is driven by the surface tension difference between the coacervate phase, the water and the hydrophobic material. Gelation is achieved by lowering the temperature of the reaction mixture below the gelling point of the gellable hydrocolloid. Permanent hardening of the microcapsule shells is achieved by cross-linking and formation of new covalent bonds or by non-covalent hardening by hydrogen bonds formed between molecules. Often both types of processes occur simultaneously or successively. Among the cross-linking agents, aldehydes (formaldehyde, glutaraldehyde) are mostly used.

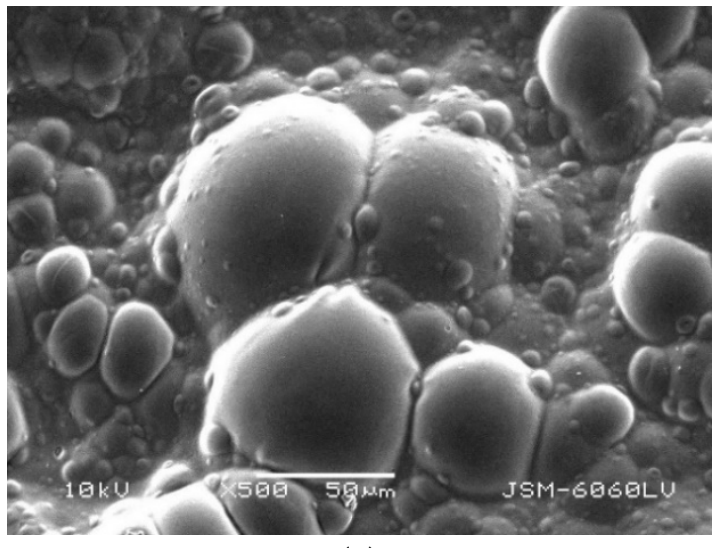

(a)

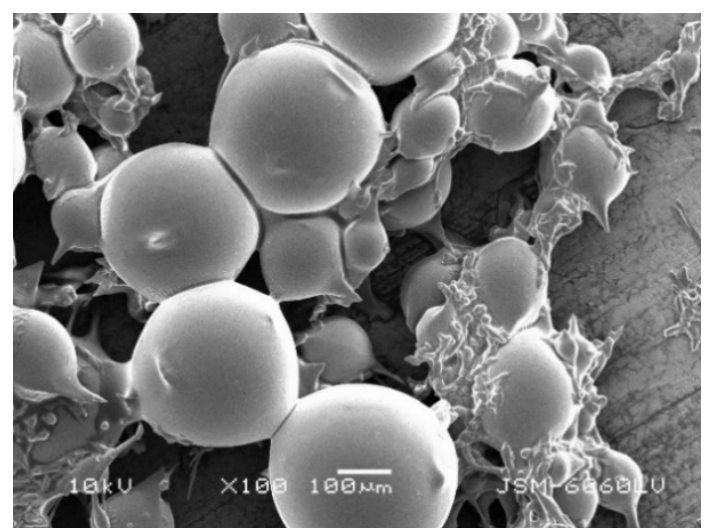

(b)

Figure 8. Complex coacervation citronella oil microcapsules with (a) gelatine-carboxymethyl cellulose shells, crosslinked with glutaraldehyde; (b) gelatine-gum Arabic shells, crosslinked with glutaraldehyde (authors' archive).

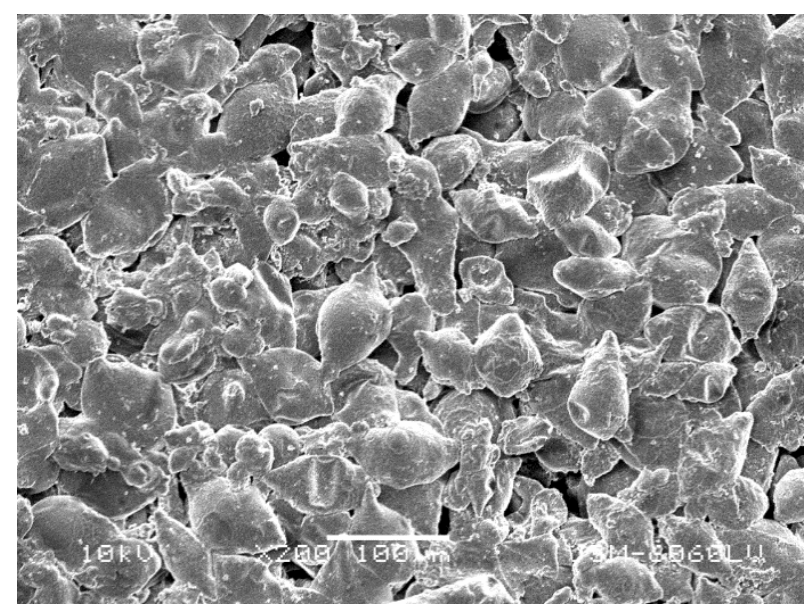

Figure 9. Complex coacervation microcapsules with exclusively natural ingredients: core of citronella oil and shells of gelatine and gum Arabic cross-linked with tannin (authors' archive).

Based on the polymer-colloid systems involved, coacervation processes are divided into two subgroups: (a) simple coacervation process, when a single polymer is involved and coacervates are formed due to reduced hydration by the addition of a salt or desolvation liquid, such as alcohol, and (b) complex coacervation, when two or more polymer colloids with opposite charges are used to form shells. Common pairs are proteins and 
polysaccharides, such as gelatine and gum Arabic. The ionic interactions between them lead to coacervate formation and phase separation. A comprehensive analysis of the coacervation processes, their mechanisms, process parameters, materials and applications has been described in [124].

\subsubsection{Molecular Inclusion with Cyclodextrins}

Cyclodextrins are cyclic oligosaccharides containing at least 6 D-(+)-glucopyranose units linked by $\alpha-(1,4)$-glucoside bonds. With lipophilic inner cavities and hydrophilic outer surfaces, they can interact with a variety of guest molecules to form non-covalent inclusion complexes that provide protection and improve solubility, bioavailability and safety of active compounds. Natural $\alpha-, \beta$ - and $\gamma$-cyclodextrins (with 6, 7 and 8 glucose units, respectively) differ in ring size and solubility, and are most frequently used $[125,126]$.

Direct interaction between cyclodextrin complexes and fibres has been reported in the functionalization of textiles. The use of poly(carboxylic) acids allows some fixation of cyclodextrin complexes to fibres. An example is the grafting of $\beta$-cyclodextrin onto hydroxyl groups of cellulose using butane-1,2,3,4-tetracarboxylic acid as crosslinking agent and sodium hypophosphite as catalyst [122].

\subsection{Physical Microencapsulation Methods for Functional Textiles}

A wide range of physical microencapsulation methods using natural shell materials have been developed to produce microcapsules for applications in pharmaceutical, food, cosmetic and detergent formulations [4,127-129]. For textiles, the range of physical microencapsulation methods is limited and restricted to a few methods, as shown in Table 3, mainly due to the higher requirements in terms of durability, mechanical strength and resistance to washing. In both spray drying and emulsification/solvent evaporation methods, the wall materials are dissolved in a solvent, the core materials are emulsified, and the active ingredient is encapsulated by the shell material after solvent evaporation. Simple emulsions or multiple reverse-phase solvent evaporation methods can be used. An advantage of physical methods is the possibility to use biodegradable materials such as acacia gum, chitosan, ethyl cellulose and polylactic acid.

Table 3. Physical microencapsulation methods used for textile functionalization-examples of processes and materials.

\begin{tabular}{cccc}
\hline Shell Materials & Core Materials & Functional Textile & Ref. No. \\
\hline & \multicolumn{2}{c}{ Spray Drying } & \\
\hline $\begin{array}{c}\text { Acacia gum. } \\
\text { Chitosan. }\end{array}$ & $\begin{array}{c}\text { Citronella oil. } \\
\text { Vanillin. }\end{array}$ & $\begin{array}{c}\text { Nonwoven cosmetic textiles. } \\
\text { Fragranced cotton fabric. }\end{array}$ & {$[$ [130] } \\
\hline Soy lecithin and cholesterol. & $\begin{array}{c}\text { Reactive dye vinylsulfone } \\
\text { azonaphthalene. }\end{array}$ & Wool textile dyeing. \\
\hline Poly-lactic acid. & $\begin{array}{c}\text { Phase change material capric acid. } \\
\text { Thermal conductivity enhancer } \\
\text { carbon nanotubes. }\end{array}$ & $\begin{array}{c}\text { 3D polyester knitted fabric with } \\
\text { enhanced thermal properties. }\end{array}$ \\
\hline Ethyl cellulose. & Immortelle essential oil. & Cosmetic and medical textiles. \\
\hline- & $\begin{array}{c}\text { Antifungal pharmaceuticals } \\
\text { terbinafine and ketoconazole. }\end{array}$ & Antifungal cotton fabrics.
\end{tabular}

\section{Microcapsule Coating Formulations and Technologies}

\subsection{Formulation Composition}

Microcapsules have to be formulated for applications on woven or non-woven textiles without significantly altering the feel or colour of the textile products. Formulation additives typically include binders, crosslinking agents, organic or inorganic pigments and fillers, defoamers and/or other surfactants and viscosity control agents/thickeners. 
Binders play a crucial role in microcapsule formulations for textiles. They largely determine the quality, durability and washability of textile materials containing microencapsulated ingredients. Typically, binders are selected from the following groups:

- Synthetic latexes, such as polyacrylate latexes, styrene-butadiene, polyvinyl-acetate, ethylene-vinyl acetate copolymers [134-137];

- Synthetic resins, such as urea-and melamine-formaldehyde resins, dimethylol ethylene urea, dimethylol dihydroxy ethylene urea, dimethylol propylene urea, polyurethane and epoxy resins, vinyl acetate resins [138-140];

- $\quad$ Synthetic rubbers, such as polyurethanes, nitrile and chloroprene rubbers $[66,139,141]$;

- $\quad$ Silicones $[89,140]$;

- Citric acid (CA) or 1,2,3,4-butanetetracarboxylic acid (BTCA) and catalysts (monobasic sodium phosphate monohydrate, sodium hypophosphite) [73,116,131,135,142,143];

- Chitosan gel [144].

The use of acrylic or polyurethane binders has predominated among other binders in the finishing of textiles with microcapsules in the last 5 years, but it must be emphasised that cotton finishing or so-called chemical grafting using CA or BTCA as crosslinker between microcapsule and cotton fibre and sodium hypophosphite as a catalyst [73,116,131,135,142,143] is on the rise due to the increasing use of biodegradable polymers (chitosan alone or chitosangum Arabic or gelatine-gum Arabic) as shell-forming materials in microcapsule production. Increased environmental awareness promoted the use of sustainable and biodegradable polymers in the finishing of textiles with microcapsules and the production of functional textiles. The advantage of using chemical grafting instead of polymeric binders is the flexibility and breathability of the textiles, which are retained after application. In contrast, polymeric binders form a binder layer during curing which can significantly reduce the air permeability of the fabric, change the tensile strength of the fabric, increase stiffness and reduce softness [73].

\subsection{Durability of Coatings}

The design of functional textiles for single use does not necessarily require the study of all types of durability to the same extent as for textiles for long-term use. When designing functional textiles with microcapsules, the performance of various basic resistances, such as resistance to rubbing, light, washing and wet- and dry cleaning, which are standardised in the textile industry, should be considered.

As mentioned above, the application of microcapsules to textiles requires the addition of a binder, as a microcapsule shell is not able to interact strongly with functional groups of textile fibres. An exception is the chemical grafting of cotton with citric acid, where citric acid is used as a non-toxic crosslinker to covalently bind the microcapsule wall material to hydroxyl groups of cotton via ester bonds [73,131]. During curing, the binder forms a thin, elastic and transparent binder layer on the textile surface in which the microcapsules are enclosed. Therefore, the adhesion between the binder layer and the textile substrate plays a crucial role.

The durability of the microcapsules and the maintenance of the functionality of the textile during its lifetime depend on the resistance of the binder layer to washing, dry and wet cleaning, rubbing and light. It should be emphasised that all washfastness properties in textiles are standardised by the standards ISO 105-C01 [131,139], ISO 105-C10 [141], ISO 105-C06, ISO 6330 or AATCC TM61 [77,89,121,136,145]. The standard ISO 105-C01 is no longer valid anymore and is replaced by ISO 105-C10. The use of non-standardised test methods does not provide reliable insight into the actual behaviour of a functional textile during the care and wearing process but can provide a rough estimate.

When functional textiles are directly involved in a domestic [70] or industrial washing, wet cleaning and dry-cleaning process [28], a more realistic assessment of the durability of the textile can be achieved as the textile is exposed to real-life care conditions (detergent, mechanical action, abrasion, temperature, time and solvent). Moreover, the washing or cleaning conditions are standardised by the machine manufacturer. 
Figure 10 shows the SEM images of a polyester fabric coated with photochromic microcapsules before and after washing, wet cleaning and dry cleaning. It can be clearly seen that the cleaning process strongly affected the adhesion between the binder layer, in which the microcapsules were enclosed, and the polyester fibres, resulting in the loss of the functional coating.

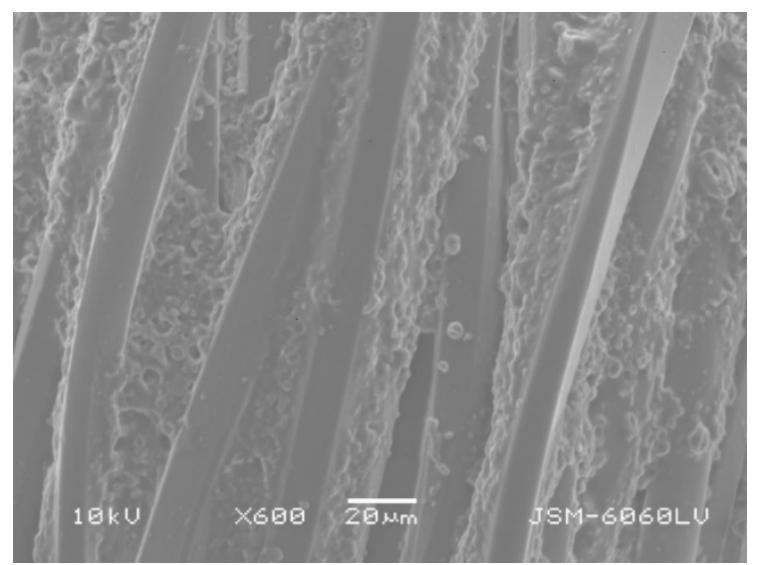

(a)

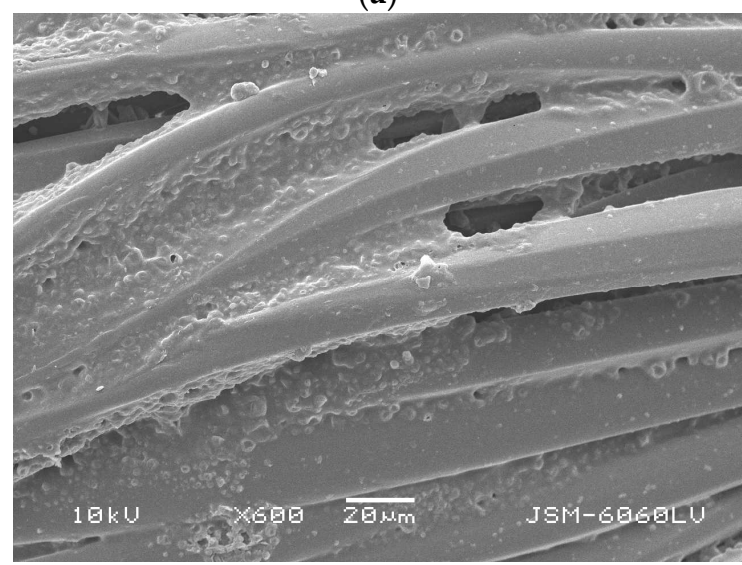

(c)

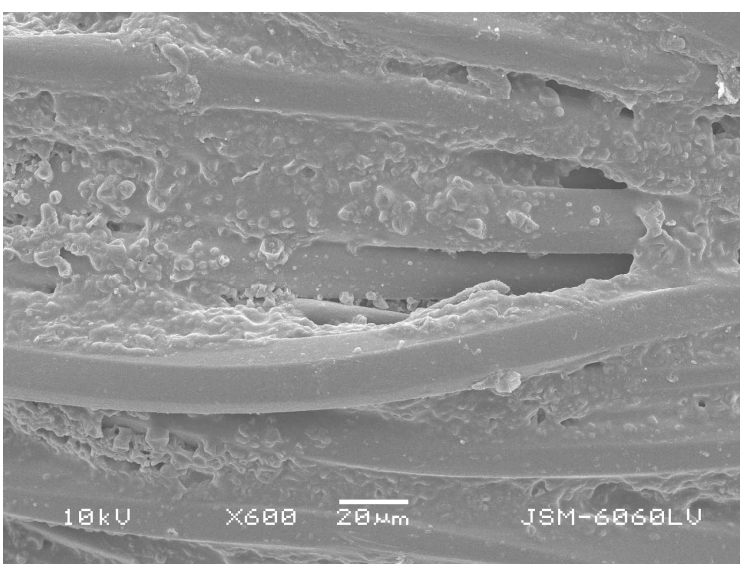

(b)

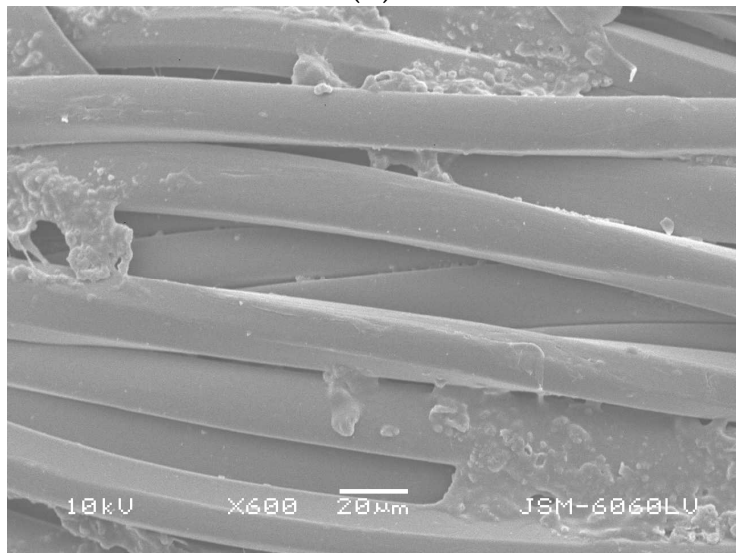

(d)

Figure 10. SEM micrographs of PES fabric coated with (a) photochromic microcapsules before cleaning, (b) after washing, (c) wet cleaning and (d) dry cleaning (authors' archive).

\subsection{Coating Techniques}

Various techniques can be used to apply microcapsules to textiles. Patents and published articles describe the incorporation of microencapsulated compounds onto textiles using the following application techniques:

- $\quad$ coating with an air knife or rod coater [146,147];

- impregnation or immersion $[28,142,148,149]$;

- exhaustion [150];

- $\quad$ printing techniques, such as screen-, photographic-, electrostatic-, pressure-transfer, thermal-transfer and inkjet printing [26,96,101,151];

- $\quad$ spraying on the surface of textiles, $[90,152,153]$.

Instead of coating techniques, some researchers developed and used other technological solutions for incorporating microcapsules into textile products, such as:

- Inclusion of microcapsules into the textile fibres during the spinning process, using polyester, nylon, polypropylene or modacryl fibre material [154-158];

- Incorporation into polymer foams, coatings and multilayer composites that are placed or inserted into selected parts of textile clothing or footwear [159-164]. 


\section{Biodegradable Functional Textiles Containing Microcapsules}

\subsection{Biodegradability of Synthetic Materials}

In general, high molecular weight synthetic polymers such as urea-formaldehyde resins, nylon, polyvinyl chloride, polystyrene and polyethylene are classified as nonbiodegradable plastics [165]. However, some microbial research has also addressed the question of whether and to what extent microorganisms can degrade plastics in the environment and has focused on biodegradation and biotreatment of plastic wastes. A recent review paper by Danso et al. [166] summarized current knowledge on microbial plastic degradation and indicated that microorganisms and enzymes can act on some high molecular weight polymers of polyethylene terephthalate and ester-based polyurethane at moderate turnover rates, while no efficient enzymes are known for the high molecular weight polymers of polystyrene, polyamide, polyvinyl chloride, polypropylene, etherbased polyurethane and polyethylene.

Although, to our knowledge, no biodegradability studies have been published specifically for aminoaldehyde microcapsules prepared by in situ polymerization or for microcapsules synthesised by interfacial polymerization with polyamide, polyurethane, polyurea or polyester shells, some publications described biodegradability studies conducted specifically with these synthetic polymeric materials in the natural environment or under controlled laboratory conditions. The following literature review provides examples of research studies on the biodegradability of generally non-biodegradable synthetic polymers.

\subsubsection{Melamine-Formaldehyde Resins}

Otake et al. [165] studied the biodegradation of polymers buried in soil for over 32 years. Remarkable degradation was found only for thin films of low-density polyethylene in direct contact with soil, while no evidence of biodegradation was found for polystyrene, polyvinyl chloride and urea-formaldehyde resin. However, from the wastewater of an aminoplast industrial plant, El Sayed et al. [167] isolated a novel bacterial strain Micrococcus sp. MF-1 that was able to use melamine-formaldehyde resin as its main carbon and nitrogen source. Melamine, cyanuric acid and biuret were detected as intermediate metabolites in the filtrate of the culture. Biodegradation of the resin proceeded via successive deamination reactions of melamine to cyanuric acid, which was hydrolysed to biuret and finally to $\mathrm{NH}_{3}$ and $\mathrm{CO}_{2}$.

\subsubsection{Polyurethane and Polyester-Polyurethane}

Polyurethane, especially polyester-polyurethane, appears to be more susceptible to microbial infestation. Nakajima-Kambe et al. [168] analysed reports on the degradation of polyester-polyurethane by microorganisms and fungi and concluded that biodegradation occurs mainly through the hydrolysis of ester bonds by esterases.

Ibrahim et al. [169] reported that out of 70 fungal isolates recovered from soils, wall paints and plastic wastes from different habitats, 35 isolates showed potential to degrade polyester polyurethane. Six of these isolates (Fusarium solani, Alternaria solani, Spicaria spp., Aspergillus fumigatus, Aspergillus terreus and Aspergillus flavus) grew on basal salt media amended with polyester-polyurethane as the sole carbon source. Maximum degradation activity was achieved by the isolate Aspergillus flavus, which caused a weight loss of $94 \%$ of the polyester-polyurethane pieces.

Khan et al. [170] isolated and characterised polyester-polyurethane degrading fungi from the soil of a general municipal solid waste landfill. Among them, a novel polyesterpolyurethane-degrading fungus was isolated and identified as Aspergillus tubingensis. Khan et al. [171] also investigated the ability of the fungus Aspergillus flavus G10, isolated from the gut of the common cricket Gryllus bimaculatus, to biodegrade polyurethane. The biodegradation was maximal in fungus cultured on a malt extract medium.

Brunner et al. [172] reported on the ability of some fungal strains to degrade plastics. Three litter-saprotrophic fungi found on floating plastic waste in the shoreline of a lake, Cladosporium cladosporioides, Xepiculopsis graminea and Penicillium griseofulvum, and the 
plant pathogen Leptosphaeria sp. were able to degrade polyurethane. In addition, two other litter-saprotrophic fungi, Agaricus bisporus and Marasmius oreades, which were not isolated from floating plastic waste, also showed the ability to degrade polyurethane.

Similarly, Russel et al. [173] screened numerous endophytic fungi for their ability to degrade polyester-polyurethane. While several isolates showed the ability to efficiently degrade polyester-polyurethane in both solid and liquid suspensions, particularly strong activity was observed in isolates of the genus Pestalotiopsis. Two isolates of the species Pestalotiopsis microspora were uniquely capable of growing on polyester polyurethane as a sole carbon source under both aerobic and anaerobic conditions and were found to be promising sources of biodiversity useful for bioremediation.

\subsubsection{Nylon/Polyamides}

The biodegradation of nylon membranes by lignin-degrading fungi was studied by Deguchi et al. [174]. The white rot fungal strain IZU-154 oxidatively degraded nylon-66 membrane under ligninolytic conditions. The nylon-degrading activity was closely related to the ligninolytic activity of the fungus.

Negoro [175] reviewed the degradation of nylon oligomers and reported that two strains that originally lacked metabolic activity for nylon oligomers, namely Flavobacterium sp. KI725 and Pseudomonas aeruginosa PAO1 developed the ability to degrade nylon oligomers as xenobiotic compounds by selective cultivation with nylon oligomers as the sole carbon and nitrogen source.

According to Sudhakar et al. [176], the marine bacteria Bacillus cereus, Bacillus sphericus, Vibrio furnisii and Brevundimonas vesicularis were shown to degrade nylon 6 and 66 in a mineral salt medium, with the polymer being the sole carbon source.

\subsubsection{Polyesters}

Kim and Rhee [177] published a review on fungal degradation of microbial and synthetic polyesters and discussed the ecological significance and contribution of fungi in the biological recycling of polymeric waste materials in the biosphere. In general, aromatic polyesters are more resistant to microbial attack. In contrast, due to their potentially hydrolysable ester bonds, most aliphatic polyesters can be mineralized by several aerobic and anaerobic microorganisms that are widely distributed in nature. To obtain useful biomaterials and reduce the impact of environmental pollution caused by non-degradable polymers, biodegradable polyesters have been developed, such as polyhydroxyalkanoates, poly(e-caprolactone), poly(L-lactide), aliphatic and aromatic polyalkylene dicarboxylic acids.

While aromatic polyesters, such as poly(ethylene terephthalate), have excellent material properties but are resistant to microbial attack, many biodegradable aliphatic polyesters lack technological properties important for the application. Aliphatic-aromatic copolyesters have been developed to combine good material properties with biodegradability. Müller et al. [178] reviewed the attempts to combine aromatic and aliphatic structures in biodegradable polyester plastics and evaluated the degradation behaviour and environmental safety of biodegradable polyesters containing aromatic components.

Based on the results of these studies, it can be assumed that synthetic microcapsule shells, such as those made from amino resins, polyurethane or polyamide, are generally not readily biodegradable in the environment, but can be biodegraded by selected and adapted strains of microorganisms and fungi.

\subsection{Biodegradable Polymers}

The rapid development of the textile industry and the use of non-biodegradable and non-biocompatible materials have had a negative impact on the environment. Due to the negative impact on the environment, biodegradable polymeric materials have been increasingly used in the last decade [179].

The rate and degree of biodegradation of fibre-forming polymers depend on several factors, of which the following are important: properties of fibre-forming polymers (chemi- 
cal structure, molecular mass, degree of polymerization, crystallinity, degree of orientation and the hydrophilicity/hydrophobicity of textile materials), environment (presence of oxygen, temperature, humidity, $\mathrm{pH}$, light and the presence of metals and salts) and microbial flora in a given environment, with appropriate secreted enzymes for the degradation of polymers [180].

Biodegradable polymers can be of natural or synthetic origin. Their heteroatoms in the main chain are potentially susceptible to hydrolytic cleavage of ester (-COO-), amide (-CONH-) or ether (-O-) bonds. Natural biodegradable polysaccharides include cellulose, chitin, chitosan, amylose, sodium alginate, lignin, etc. Other biodegradable polymers include amide-containing polymers (polypeptides, proteins and thermal polyaspartate), biodegradable polyurethane and polyesters such as polycaprolactone (PCL), polylactic acid (PLA), poly(3-hydroxybutyrate), polyhydroxyalkanoates (PHAs) and their corresponding copolymers [181].

Polysaccharides, especially cellulose, are widely used in the textile industry due to their nontoxicity, biodegradability and biocompatibility [182]. Cotton, a natural cellulose fibre, is the most used material. Due to its specific structure, cotton becomes stronger when it is wet. This makes the material suitable for textiles that need to be washed frequently. Due to the numerous functional groups on the chains, the structure can be chemically modified to improve the chemical, physical and biological properties [183].

\subsection{Biodegradability Testing}

From the large number of standards available for testing the biodegradability of various materials, the following standardised test methods have been developed and used specifically for evaluating the biodegradability of textile materials:

- 21701:2019 Textiles-Test method for accelerated hydrolysis of textile materials and biodegradation under controlled composting conditions of the resulting hydrolysate,

- ISO 11721-1:2001 Textiles-Determination of resistance of cellulose-containing textiles to micro-organisms-Soil burial test-Part 1: Assessment of rot-retardant finishing,

- ISO 11721-2:2003 Textiles-Determination of the resistance of cellulose-containing textiles to micro-organisms-Soil burial test-Part 2: Identification of long-term resistance of a rot retardant finish,

- $\quad$ AATCC TM30: 2013 Antifungal activity, assessment on textile materials: Mildew and rot resistance of textile materials, Test 1 soil burial,

- $\quad$ ASTM D 5988-18 Standard test method for determining aerobic biodegradation of plastic materials in soil)

The soil burial test has been the most used in published articles [180,184-190]. In this test, the sample is buried in the soil for a certain time under specific conditions (temperature, humidity, $\mathrm{pH}$ ) specified in the standard. After the specified burial time, the samples are removed from the soil, rinsed and dried. The burial time is specified in the standards with the loss of the maximum tensile strength of the tested sample, which can be $80 \%$ or $90 \%$ depending on the standard. Figure 11 shows the biodegradation of chemically bleached cotton fabric using the burial test (ISO 11721-1:2001), where the biodegradation of the fibres is visually apparent and accelerated by increasing the burial time.

During the biodegradation process, many changes occur, and the textile material exhibits significant optical and other morphological changes. In the study of textile biodegradation, the colour change of buried textile material is evaluated spectrophotometrically by calculating the colour difference between the unburied and buried samples, surface changes of fabrics are also characterised by optical microscopy, morphological changes of fibres are characterised by scanning electron microscopy (SEM), changes in fibre crystallinity and internal structure by X-ray diffraction (XRD), the chemical structure of the textile material or its functional groups by Fourier transform infrared spectroscopy (FTIR), the change in thermal stability of the buried textile material by thermal gravimet-ric analysis (TGA) and mechanical changes by a mechanical test that determines the loss of breaking strength of the textile material [185,187-191]. 

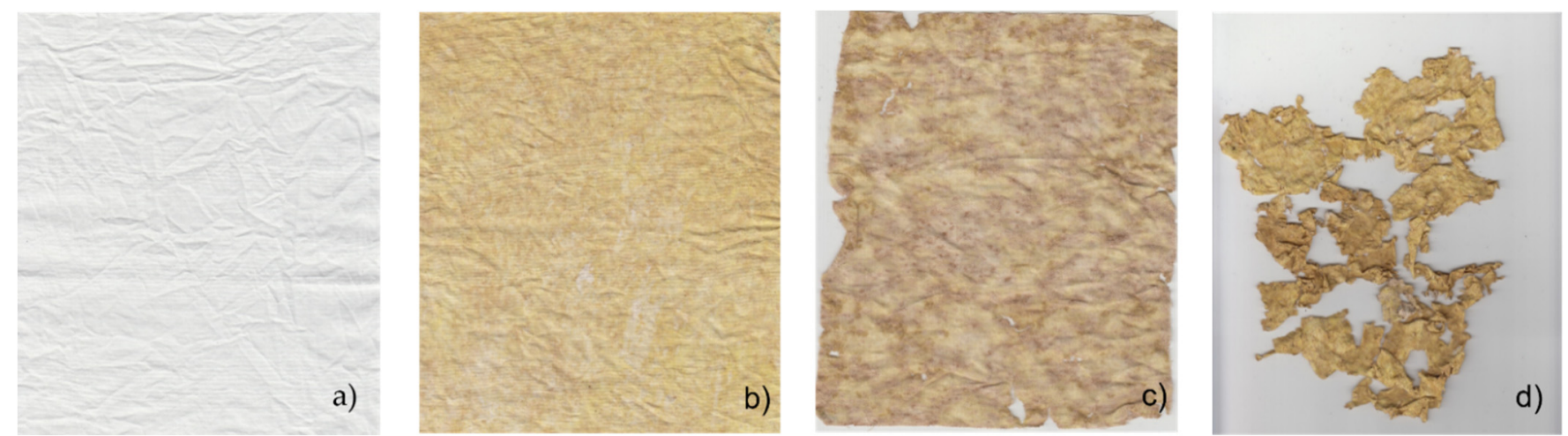

Figure 11. Biodegradation of chemically bleached cotton fabric before (a) and after 6 (b), 12 (c) and 18 (d) days of soil burial (research archive, Brigita Tomšič).

Previous studies on the biodegradation of a cotton fabric using the soil burial test have shown that biodegradation is very rapid in untreated cotton, whereas biodegradation in treated cotton depends on the finishing treatment [184,191]. The crosslinked finishes on cotton fabrics showed lower biodegradation than the non-crosslinked finishes [184]. The results of breaking strength indicated that finished cotton textiles degraded more slowly than raw cotton fabrics. The prolongation of time depended on the finishing treatment [191]. Fabric construction parameters (weave, linear density and thickness) were found to affect biodegradability. Fabrics with looser weave and lower linear density showed greater loss of tensile strength than fabrics with denser weave and higher linear density. Thinner fabric degraded faster than thicker fabric [177]. The hairiness of the fabric surface and the relative tightness of the yarn twist had a major effect on the speed of cellulolytic attack [187]. The inhomogeneity of textile fibres (amorphous/crystalline region, surface porosity, fibre diameter, some damages, etc.) could be the cause of the uneven biodegradation of the fabric [188]. The degradation of cotton resulted in a change in fabric colour $[186,187,189,190]$, which was closely related to the burial time and finishing. The degree of polymerization of the cotton fabric decreased with increasing burial time. The intensity of the bands at 1640 and $1548 \mathrm{~cm}^{-1}$ in the FTIR analysis corresponded to the amide I and amide II groups as a result of protein production by microbial growth on the fibres $[189,190]$. The increase in temperature and moisture content in the soil accelerated the biodegradation process as the microorganisms in the soil became more active $[180,187]$.

\subsection{Biodegradable Microcapsules for Functional Textiles}

One of the major challenges in the functionalization of textile materials is the production of biodegradable textiles containing biodegradable microcapsules. The extent to which this area remains unexplored can be seen in Figure 12, which shows the number of scientific articles and patents on microencapsulation for biodegradable and eco-friendly textiles.

Compared to Figure 1, in 2020, for example, biodegradable microcapsules were mentioned in one out of eighteen articles and one out of twelve patents on the topic of microencapsulation for textiles. In the mid 1990s, a scientific article first mentioned that the use of microcapsules would contribute to the biodegradability of medical textiles in the future [179]. In recent years, the interest of scientists in the development of biodegradable textiles containing microcapsules has increased significantly, especially to produce antimicrobial microcapsules, dominated by essential oils and plant extracts.

Microcapsules made from biodegradable materials have been applied to natural textile materials, mostly cotton $[19,73,180]$. The choice of techniques for the preparation of biodegradable microcapsules is even more limited since chemical polymerization methods are not applicable. Therefore, physico-chemical and physical methods have been used (Table 4). Among the biodegradable polymers used to form the microcapsule shell, chitosan, gum Arabic and alginate predominate, while polylactic acid, soy lecithin, cholesterol and $\beta$-cyclodextrin are used to a lesser extent. 


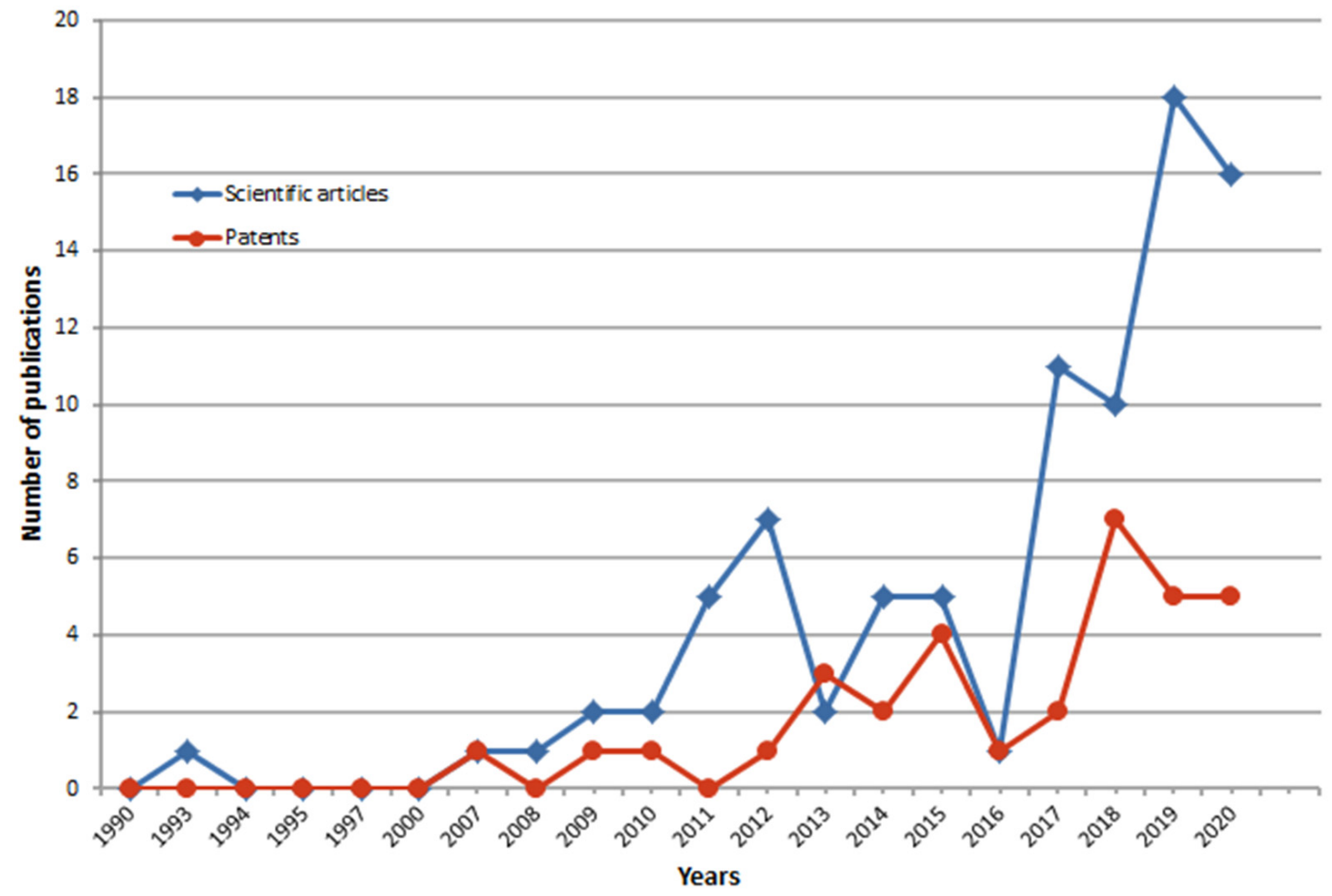

Figure 12. Trends in the number of the scientific articles in the Web of Science database [10] and patent documents in Espacenet database [11] on the topic of microencapsulation for biodegradable and environmentally friendly textiles. Search query (Web of science): (microcapsule* OR microencapsulat*) AND (textile* OR cloth OR fabric OR garment ${ }^{*}$ ) AND (biodegrada* OR eco-friend* OR green OR biopolymer* OR biocompatib ${ }^{*}$ ). Search query (Espacenet): microcapsule* AND textile* environment ${ }^{*}$.

The degradability of microcapsule cores depends on the ingredients used. An overview of the biodegradable microcapsules in Table 4 shows that the core material is usually composed of natural compounds which, through controlled release from the microcapsule into the environment, impart specific functional activity to the textile, such as antimicrobial, anti-inflammatory, insect repellent or fragrance properties. Essential oils such as basil, cinnamon, clove, citronella limonene, lavender and vanillin predominate among core materials, along with other natural ingredients such as rice oil and wintergreen oil (methyl salicylate), propolis and capric acid as a saturated fatty acid. Essential oils are natural, volatile and aromatic liquids, extracted mainly from plants, and are easily degradable in the environment under suitable conditions, namely light, heat and atmospheric oxygen [192].

Cotton fabric as a biodegradable textile is commonly used as a textile material for microcapsule application. The most commonly used method for applying biodegradable microcapsules to textiles is the pad-dry-cure or pad-dry process, although screen printing may also be used. The type of coating technique can affect the rate of biodegradation, particularly if the application of the microcapsules and other chemicals required for adhesion of microcapsules to fibres increases the hydrophilicity of the textile. Hydrophilic textile surface is more susceptible to moisture absorption, which in turn accelerates the rate of textile biodegradation by microorganisms and fungi. Padding is usually accomplished by immersing the textile in a padding bath containing a suspension of microcapsules of varying concentrations with no or added binders to ensure adhesion of the microcapsules to the fibre. The duration of the immersion can last from one to several minutes, depending on the characteristics of the textile (linear density, hydrophilicity and thickness) and its ability to absorb the padding bath. The fabric wet pick-up is controlled by the pressure of the rollers during squeezing of the padded fabric.

In recent years, synthetic additives in the padding bath (acrylate binders or even less environmentally friendly dimethylol dihidroxyethlylene urea, wetting and softening 
agents) have been successfully replaced by more promising green products based on chemical grafting of cellulose with citric acid as crosslinker and monosodium phosphate as catalyst. Microbial degradation of acrylic polymers can be carried out for some types of polymers and to some extent. The biodegradation of acrylic polymers depends on the structure of the polymer, such as $\mathrm{C}-\mathrm{C}$ backbone length, side groups, quaternary carbons and molecular organisation (linear, branched or cross-linked), as well as on the microorganisms and the environment in which the process is carried out, and the techniques used to quantify acrylic polymers degradation. Other characteristics such as the purity of the product and the degree of hydrolysis also influence the acrylic polymer biodegradability assessment [193]. On the other hand, dimethylol dihidroxyethylene urea reduces the hydrophilicity of the cotton fabric due to a cross-linking reaction that takes place in the amorphous regions of the fibre. The finished cotton is less wettable and can absorb less moisture from the environment, which is one of the factors that accelerate biodegradation. In addition, dimethylol dihidroxyethylene urea impairs the growth conditions for microorganisms and thus delays the biodegradation of cotton fabric [190]. It should be emphasised that there is no clear limit to what is biodegradable and what is not, as some of the polymers cannot be degraded in natural environments, sludge or landfills, but only in a specific artificial environment by selected microorganisms and fungi, as already discussed in chapter 7.1.

In practice, achieving the biodegradability of products often results in diminished or limited technological performance of products. Therefore, functionalized textiles containing biodegradable microcapsules should be tested for their resistance to washing, rubbing and light, especially if the functional textiles are intended for daily use. Although few studies tested the wash resistance of functionalized textiles, the test methods used were poorly described or even not standardised. Future work should focus on testing various durability properties of functional textiles, including those with biodegradable microcapsules, using only standardised methods.

In the available literature, there are only a limited number of studies [194-196] that focussed on and specifically investigated the biodegradation of microcapsules. Since there is no standardised test method to evaluate the biodegradability of microcapsules, the next step would be to develop guidelines for testing or to create a new standard.

Table 4. Biodegradable microcapsules for functionalization of biodegradable textiles.

\begin{tabular}{|c|c|c|c|c|c|}
\hline Shell Materials & Core Materials & $\begin{array}{l}\text { Coating } \\
\text { Composition } \\
\text { Additives }\end{array}$ & $\begin{array}{l}\text { Application } \\
\text { Method }\end{array}$ & Functional Textile & Ref. No. \\
\hline \multicolumn{6}{|c|}{ Simple Coacervation } \\
\hline \multirow{2}{*}{ Chitosan. } & $\begin{array}{l}\text { Cinnamon } \\
\text { essential oil. }\end{array}$ & $\begin{array}{l}\text { Dimethylol } \\
\text { dihydroxy } \\
\text { ethylene urea. }\end{array}$ & Pad-pre-dry-cure. & $\begin{array}{l}\text { Antimicrobial cotton } \\
\text { woven fabric. }\end{array}$ & [70] \\
\hline & $\begin{array}{l}\text { Cinnamon and clove } \\
\text { essential oil. }\end{array}$ & $\begin{array}{l}\text { Citric acid, } \\
\text { monosodium } \\
\text { phosphate. }\end{array}$ & $\begin{array}{l}\text { Immersion-dry- } \\
\text { cure. }\end{array}$ & $\begin{array}{l}\text { Antimicrobial } \\
\text { cotton fabric. }\end{array}$ & [192] \\
\hline $\begin{array}{l}\text { Mypro gum or } \\
\text { sodium } \\
\text { alginate. }\end{array}$ & $\begin{array}{c}\text { Extract of } \\
\text { Pelargonium hortorum. }\end{array}$ & $\begin{array}{c}\text { Citric acid or } \\
\text { commercial binder }\end{array}$ & Pad-dry-cure. & $\begin{array}{l}\text { Antimicrobial and } \\
\text { anti-inflammatory } \\
\text { cotton woven fabric. }\end{array}$ & [145] \\
\hline
\end{tabular}


Table 4. Cont

\begin{tabular}{|c|c|c|c|c|c|}
\hline Shell Materials & Core Materials & $\begin{array}{c}\text { Coating } \\
\text { Composition } \\
\text { Additives } \\
\end{array}$ & $\begin{array}{l}\text { Application } \\
\text { Method }\end{array}$ & Functional Textile & Ref. No. \\
\hline & & Complex Coa & ation & & \\
\hline \multirow{2}{*}{$\begin{array}{l}\text { Chitosan, } \\
\text { gum Arabic. }\end{array}$} & $\begin{array}{l}\text { Vanillin or } \\
\text { limonene } \\
\text { essential oil. }\end{array}$ & $\begin{array}{l}\text { Citric acid } \\
\text { and sodium } \\
\text { phosphate } \\
\text { monobasic } \\
\text { monohydrate. }\end{array}$ & Immersion-dry-cure. & $\begin{array}{l}\text { Antimicrobial } \\
\text { cotton fabric. }\end{array}$ & [73] \\
\hline & $\begin{array}{l}\text { Lavender } \\
\text { essential oil. }\end{array}$ & $\begin{array}{l}\text { Citric acid } \\
\text { and sodium } \\
\text { phosphate } \\
\text { monobasic } \\
\text { monohydrate. }\end{array}$ & Pad-dry. & $\begin{array}{l}\text { Antimicrobial } \\
\text { cotton fabric. }\end{array}$ & [135] \\
\hline \multirow{3}{*}{$\begin{array}{l}\text { Gelatine, } \\
\text { gum Arabic }\end{array}$} & Propolis, rice oil. & Acrylate binder. & Pad-dry. & $\begin{array}{l}\text { Antimicrobial } \\
\text { cotton fabric. }\end{array}$ & [118] \\
\hline & Methyl salicylate. & $\begin{array}{c}\text { Citric acid } \\
\text { and sodium } \\
\text { hypophosphite. }\end{array}$ & Pad-dry-cure. & $\begin{array}{l}\text { Anti-inflammatory } \\
\text { and analgesic cotton } \\
\text { and polyamide knitwear. }\end{array}$ & [77] \\
\hline & $\begin{array}{l}\text { Citronella } \\
\text { essential oil. }\end{array}$ & - & Pad-dry. & $\begin{array}{l}\text { Insect/Mosquito } \\
\text { repellent cotton and } \\
\text { polyester fabric. }\end{array}$ & [197] \\
\hline $\begin{array}{l}\text { Gelatine, } \\
\text { alginate. }\end{array}$ & $\begin{array}{l}\text { C. aurantifolia } \\
\text { essential oil. }\end{array}$ & Citric acid & Pad-dry-cure. & $\begin{array}{l}\text { Antimicrobial cotton } \\
\text { fabric. }\end{array}$ & [71] \\
\hline \multicolumn{6}{|c|}{ Molecular Inclusion } \\
\hline $\begin{array}{l}\text { Epichlorohydrin } \\
\text { modified } \\
\beta \text {-cyclodextrin. }\end{array}$ & $\begin{array}{c}\text { Lavender } \\
\text { essential oil, } \\
\text { indigo powder. }\end{array}$ & - & $\begin{array}{l}\text { Immersion-freeze } \\
\text { dried }\end{array}$ & $\begin{array}{l}\text { Bifunctional dyed } \\
\text { and fragranced } \\
\text { cotton woven fabric. }\end{array}$ & [121] \\
\hline \multicolumn{6}{|c|}{ Emulsification and Solvent Evaporation } \\
\hline $\begin{array}{l}\text { Soy lecithin, } \\
\text { cholesterol. }\end{array}$ & $\begin{array}{c}\text { Reactive dye } \\
\text { (vinylsulphone } \\
\text { azonaphthalene). }\end{array}$ & $\begin{array}{c}\text { Acetic acid, } \\
\text { sodium sulphate. }\end{array}$ & Dyeing. & Dyed wool fabric & [19] \\
\hline Polylactic acid. & $\begin{array}{c}\text { Bio based PCM, } \\
\text { (capric acid, } \\
\text { multiwall carbon } \\
\text { nanotube). }\end{array}$ & - & Screen printing. & $\begin{array}{l}\text { Thermo-regulated } \\
\text { 3D polyester } \\
\text { knitwear. }\end{array}$ & [39] \\
\hline \multicolumn{6}{|c|}{ Emulsification and Crosslinking } \\
\hline Chitosan. & Basil oil. & Acrylic binder. & Immersion-drying. & $\begin{array}{c}\text { Antimicrobial } \\
\text { Tencel/ } \\
\text { polyurethane fabric. }\end{array}$ & [198] \\
\hline \multicolumn{6}{|c|}{ Spray-Drying } \\
\hline Chitosan. & $\begin{array}{c}\text { Vanillin } \\
\text { essential oil. }\end{array}$ & $\begin{array}{c}\text { Citric acid } \\
\text { and sodium } \\
\text { hypophosphite. }\end{array}$ & $\begin{array}{l}\text { Immersion-dry- } \\
\text { cure. }\end{array}$ & $\begin{array}{l}\text { Fragranced cotton } \\
\text { fabric. }\end{array}$ & [131] \\
\hline \multicolumn{6}{|c|}{ SOL-GEL } \\
\hline $\begin{array}{l}\text { Tetraethoxy-silane-- } \\
\text { TEOS. }\end{array}$ & Paraffin PCM. & - & Pad-dry-cure. & $\begin{array}{l}\text { Thermo-regulated } \\
\text { cotton fabric. }\end{array}$ & [199] \\
\hline
\end{tabular}




\subsection{Opportunities for Further Research}

According to the available market reports, the microcapsules market is estimated to reach USD 8.4 billion in 2021 and USD 13.4 billion by 2026 [200] and USD 17.31 billion by 2027 [201], at an intensive compound annual growth rate of 9.8\% from 2021 to 2026 (200) and $11.7 \%$ from 2020 to 2027 [201] for various vertical end-uses such as pharmaceuticals and healthcare, food, home and personal care, textiles, agrochemicals and others [200].

Research and development should focus on the production of environmentally friendly, biodegradable microcapsules that are less harmful to the environment than the use of classic synthetic shell materials, which are difficult to degrade and pose a serious environmental problem in the long term. More effective adhesion between microcapsules and textile fibres must be developed to reduce the losses of microcapsules into the wastewater during the washing process.

There is a need to move away from non-degradable synthetic materials not only in the synthesis of microcapsules, but especially in the production of textile substrates, which contribute to the accumulation of solid waste, and to microplastic pollution of habitats via textile laundering wastewater [202,203]. However, it should be highlighted that the cultivation of cellulosic fibres for cotton, on the other hand, requires large amounts of water for plant growth, with intensive use of fertilisers, pesticides and defoliants, all of which pose environmental challenges [204].

The classical textile pre-treatment processes of desizing, scouring and bleaching, which are crucial for making textiles suitable for adsorption of microcapsules, textile auxiliaries, dyes and pigments, need to be changed towards the use of environmentally friendly chemicals such as amylases, pectinases and hydrogen peroxide [205,206]. Functionalization of textiles can be achieved using classical finishing agents and methods without or with microcapsules to provide water and oil repellent, flame retardant or antimicrobial properties. The other option is the application of nanoparticles or microcapsules using more sustainable and environmentally friendly technologies, namely plasma [207] and sol-gel technology [208].

\section{Conclusions}

In the production of functional textiles, microencapsulation is used to improve properties or provide completely new functionalities, resulting in broader usability and higher added value of the products.

Trends in publications on microcapsules for functional textiles show a growing number of new scientific articles and patent documents, indicating strong interest in this field. Main functionalities achieved with microcapsules in textile coatings include thermochromic and photochromic effects, flame retardancy, improved thermal regulation, superhydrophobicity, UV absorption, insecticidal and insect repellent effects, prolonged release of fragrances, antimicrobial properties and special medical or cosmetic effects.

Microencapsulation has been used to impart properties to textiles that are not possible or cost effective with other technologies. For example, liquids cannot be retained on textiles. Permanent separation of a core material without release allows liquid actives to be converted into solid discrete particles that remain functional in the textile coating throughout the life of the product, as in the case of paraffinic PCMs of photochromic substances. Volatile compounds would evaporate too quickly from textiles; microcapsules with permeable shells allow sustained release by diffusion, as in the case of essential oils. Rapid release from microcapsules can be planned and triggered by external stimuli, namely pressure, abrasion or combustion, as in the case of pressure-sensitive fragrance textiles or flame-resistant textile products.

Not all microencapsulation methods are specifically suitable for textile applications. Commonly used methods include in situ and interfacial polymerization, simple and complex coacervation, molecular inclusion and solvent evaporation from an emulsion. Each of these methods has advantages and disadvantages. Aminoaldehyde microcapsules prepared by in situ polymerization are widely used due to their excellent technological 
properties, including high impermeability, durability and shell resistance to chemical agents. However, aminoplast shells release small amounts of formaldehyde and are not readily degradable in the environment. Physico-chemical and physical methods allow the use of environmentally friendly shell materials that are safer to use and degrade more rapidly. However, lower resistance to technological parameters in the application of microcapsule coatings and in washing of textile products remains an important obstacle.

Most of the traditional coating processes have been used for microcapsule-containing coatings, provided that the microcapsules are small enough and can withstand the process parameters such as temperature and pressure. Binders play a crucial role in coating formulations. Acrylic and polyurethane binders have become popular in textile finishing, while organic acids and catalysts for chemical grafting are gaining ground as crosslinkers between microcapsule shells and cotton fibres. There still seems to be much room and challenges to be explored and solved in this field to increase the durability of microcapsules on textiles during use and maintenance of textile products.

There are standardised test methods recommended to evaluate the stability of microcapsules during use and care of textiles, especially the standards for washfastness properties, such as ISO 105-C06, ISO 105-C08, ISO105-C09, ISO 105-C10 and ISO 6330. The use of non-standardised test methods can only provide rough estimates, which makes comparison between different studies difficult.

One of the greatest challenges for research in the field of functionalization of textiles is the production of environmentally friendly biodegradable textiles containing biodegradable microcapsules. This area is just beginning to emerge and is still largely unexplored. The choice of techniques and materials to produce biodegradable microcapsules and coatings is even more limited, as chemical polymerization methods and synthetic polymers are mostly not applicable. So far, published studies have used physicochemical and physical microencapsulation methods using natural polymers such as chitosan, gum Arabic and gelatine or biodegradable synthetic polymers such as PLA. The biodegradability of microcapsules before and after their application on textile substrates needs further investigation. One of the main obstacles to the widespread application of biodegradable microcapsules in functional textiles is their unsatisfactory durability and resistance to washing, rubbing and light, which are crucial from the perspective of textile care and of lasting functionality. Further research should investigate the possibilities of introducing new biodegradable materials for microcapsule shells and coating compositions with improved technological properties or using functional groups on the microcapsule shell to enable the formation of covalent bonds with the functional groups of the biodegradable textiles, so that a higher adhesion between microcapsule and fibre could be achieved.

Author Contributions: Conceptualization, B.B.P. and M.K.; methodology, B.B.P. and M.K.; formal analysis, B.B.P., S.Š. and M.K.; writing—original draft preparation, B.B.P., S.Š. and M.K.; writing-review and editing, B.B.P. and M.K.; visualization, B.B.P., S.Š. and M.K.; supervision, B.B.P. All authors have read and agreed to the published version of the manuscript.

Funding: This research was supported by the Slovenian Research Agency, project Grant No. P2-0213 Textiles and ecology.

Institutional Review Board Statement: Not applicable.

Informed Consent Statement: Not applicable.

Data Availability Statement: No new data were created or analyzed in this study. Data sharing is not applicable to this article.

Acknowledgments: The authors would like to thank the colleagues in the department who contributed their unpublished photographs: Boštjan Šumiga for Figure 6 and Brigita Tomšič for Figure 11.

Conflicts of Interest: The authors declare no conflict of interest. 


\section{References}

1. Fanger, G.O. Microencapsulation: A Brief History and Introduction. In Microencapsulation-Processes and Applications; Vandegaer, J.E., Ed.; Plenum Press: New York, NY, USA; London, UK, 1974; pp. 1-20, ISBN 978-1-4684-0739-6.

2. Versic, R.J.; Barrett, K. Green the Father of Microencapsulation. Bioencapsul. Innov. 2013, 2-3.

3. Urbas, R.; Milošević, R.; Kašiković, N.; Pavlović, Ž.; Stankovič Elesini, U. Microcapsules Application in Graphic Arts Industry: A review on the state-of-the-art. Iran. Polym. J. 2017, 26, 541-561. [CrossRef]

4. Huang, K.; Yuan, Y.; Baojun, X. A Critical Review on the Microencapsulation of Bioactive Compounds and Their Application. Food Rev. Int. 2021, 1-41. [CrossRef]

5. Bakry, A.M.; Abbas, S.; Ali, B.; Majeed, H.; Abouelwafa, M.Y.; Mousa, A.; Liang, L. Microencapsulation of Oils: A Comprehensive Review of Benefits, Techniques, and Applications. Compr. Rev. Food Sci. Food Saf. 2016, 15, 143-182. [CrossRef] [PubMed]

6. Podgornik Boh, B.; Starešinič, M. Microencapsulation Technology and Applications in Added-Value Functional Textiles. In Microencapsulation: Innovative Applications; Giamberini, M., Fernandez Prieto, S., Tylkowski, B., Eds.; De Gruyter: Berlin, Germany; München, Germany; Boston, MA, USA, 2015; pp. 37-76. ISBN 9783110331875. [CrossRef]

7. Abdul Aziz, F.R.; Jai, J.; Raslan, R.; Subuki, I. Microencapsulation of Essential Oils Application in Textile: A Review. Adv. Mat. Res. 2015, 1113, 346-351. [CrossRef]

8. Poncelet, D.; Boh, B. Microcapsules Deliver. Chem. Ind. 2008, 72, 23-25.

9. Boh, B.; Sajovic, I.; Voda, K. Microcapsule Applications: Patent and Literature Analysis. In Microcapsule Patents and Products; The MML Series; Arshady, R., Boh, B., Eds.; CITUS: London, UK, 2003; Volume 6, pp. 85-156. ISBN 0953218767.

10. Clarivate. Web of Science. Available online: https:// www.webofknowledge.com (accessed on 18 August 2021).

11. European Patent Office. Espacenet Patent Search. Available online: https://worldwide.espacenet.com/ (accessed on 18 August 2021).

12. Rani, S.; Goel, A. Microencapsulation Technology in Textiles: A Review Study. Pharma Innov. J. 2021, SP-10, 660-663. Available online: https:/ / www.thepharmajournal.com/archives/2021/vol10issue5S/PartJ/S-10-5-64-493.pdf (accessed on 18 August 2021).

13. Nadi, A.; Boukhriss, A.; Bentis, A.; Jabrane, E.; Gmouh, S. Evolution in the Surface Modification of Textiles: A Review. Text. Prog. 2018, 50, 67-108. [CrossRef]

14. Boh Podgornik, B.; Starešinič, M. Microencapsulation Technology and Applications in Added-Value Functional Textiles. Phys. Sci. Rev. 2016, 1, 20150003. [CrossRef]

15. Starešinič, M.; Šumiga, B.; Boh, B. Microencapsulation for Textile Applications and Use of SEM Image Analysis for Visualisation of Microcapsules. Tekstilec 2011, 54, 80-103. Available online: http://www.tekstilec.si/wp-content/uploads/2011/04/ Microcapsulation-for-Textile-Application-and-Use-of-SEM-Image-Analysis-for-Visualisation-of-Microcapsules.pdf (accessed on 19 August 2021).

16. Ocepek, B.; Forte-Tavčer, P. Microencapsulation in Textiles. Tekstilec 2008, 51, 216-230. Available online: http:/ /www.tekstilec.si/ wp-content/uploads/2008/09/Mikrokapsuliranje-na-podro\%C4\%8Dju-tekstilstva.pdf (accessed on 19 August 2021).

17. Boh, B.; Knez, E.; Starešinič, M. Microcapsules in Textile Industry. In Microcapsule Patents and Products; The MML Series; Arshady, R., Boh, B., Eds.; CITUS: London, UK, 2003; Volume 6, pp. 235-269. ISBN 0953218767.

18. Nelson, G. Application of Microencapsulation in Textiles. Int. J. Pharm. 2002, 242, 55-62. [CrossRef]

19. Zhao, F.; Rao, B.; Xue, W.; Wang, F.; Li, C.; Lao, J.; Wang, L. The Development of Eco-Friendly Dye Microcapsules for Wool Fabric Dyeing Application. J. Polym. Environ. 2019, 27, 1202-1211. [CrossRef]

20. Nelson, G. Microencapsulated Colourants for Technical Textile Application. In Advances in the Dyeing and Finishing of Technical Textiles; Woodhead Publishing: Oxford, UK; Cambridge, UK; Philadelphia, PA, USA; New Delhi, India, 2013; pp. 78-104. [CrossRef]

21. She, F.Y.; Qi, D.M.; Chen, Z.J.; Shao, J.Z.; Yang, L. Preparation of Organic Pigment Microcapsules and its Application in Pigment Printing of Silk Fabric. Adv. Mater. Res. 2012, 441, 145-149. [CrossRef]

22. Shi, M.; Lu, B.; Li, X.; Jin, Y.; Ge, M. Thermochromic Luminescent Fiber Based on Yellow Thermochromic Microcapsules: Preparation, Properties, and Potential Application Areas. Cellulose 2021, 28, 5005-5018. [CrossRef]

23. Tözüm, M.S.; Alay Aksoy, S.; Alkan, C. Manufacturing Surface Active Shell and Bisphenol A Free Thermochromic Acrylic Microcapsules for Textile Applications. Int. J. Energy Res. 2021, 45, 7018-7037. [CrossRef]

24. Tözüm, M.S.; Alkan, C.; Alay Aksoy, S. Preparation of Poly (Methyl Methacrylate-Co-Ethylene Glycol Dimethacrylate-CoGlycidyl Methacrylate) Walled Thermochromic Microcapsules and Their Application to Cotton Fabrics. J. Appl. Polym. Sci. 2020, 137, 48815. [CrossRef]

25. Wu, Z.; Ma, X.; Zheng, X.; Yang, W.; Meng, Q.; Zheng, Z. Synthesis and Characterization of Thermochromic Energy-Storage Microcapsule and Application to Fabric. J. Text. Inst. 2014, 105, 398-405. [CrossRef]

26. Hozić, N.; Kert, M. Influence of Different Colourants on Properties of Cotton Fabric, Printed with Microcapsules of Photochromic Dye. Tekstilec 2019, 62, 208-218. [CrossRef]

27. Fan, F.; Wu, Y. Photochromic Properties of Color-Matching, Double-Shelled Microcapsules Covalently Bonded onto Cotton Fabric and Applications to Outdoor Clothing. J. Appl. Polym. Sci. 2017, 134, 44698. [CrossRef]

28. Kert, M.; Gorjanc, M. The Study of Colour Fastness of Commercial Microencapsulated Photoresponsive Dye Applied on Cotton, Cotton/Polyester and Polyester Fabric Using a Pad-Dry-Cure Process. Color. Technol. 2017, 133, 491-497. [CrossRef]

29. Fan, F.; Zhang, W.; Wang, C. Covalent Bonding and Photochromic Properties of Double-Shell Polyurethane-Chitosan Microcapsules Crosslinked onto Cotton Fabric. Cellulose 2015, 22, 1427-1438. [CrossRef] 
30. Sheng, M.; Zhang, L.; Jiang, S.; Yang, L.; Zaaboul, F.; Fu, S. Bioinspired Electro-Responsive Multispectral Controllable Dye-Doped Liquid Crystal Yolk-Shell Microcapsules for Advanced Textiles. ACS Appl. Mater. Interfaces 2021, 13, 13586-13595. [CrossRef] [PubMed]

31. Wang, C.; Jiang, X.; Cui, P.; Sheng, M.; Gong, X.; Zhang, L.; Fu, S. Multicolor and Multistage Response Electrochromic ColorMemory Wearable Smart Textile and Flexible Display. ACS Appl. Mater. Interfaces 2021, 13, 12313-12321. [CrossRef] [PubMed]

32. Sheng, M.; Zhang, L.; Wang, D.; Li, M.; Li, L.; West, J.L.; Fu, S. Fabrication of Dye-Doped Liquid Crystal Microcapsules for Electro-Stimulated Responsive Smart Textiles. Dye. Pigment. 2018, 158, 1-11. [CrossRef]

33. Li, Y.; Wang, B.; Sui, X.; Xie, R.; Xu, H.; Zhang, L.; Zhong, Y.; Mao, Z. Durable Flame Retardant and Antibacterial Finishing on Cotton Fabrics with Cyclotriphosphazene/Polydopamine/Silver Nanoparticles Hybrid Coatings. Appl. Surf. Sci. 2018, 435, 1337-1343. [CrossRef]

34. Golja, B.; Šumiga, B.; Boh, B.; Medved, J.; Pušič, T.; Forte Tavcer, P. Application of Flame Retardant Microcapsules to Polyester and Cotton Fabrics. Mater. Tehnol. 2014, 48, 105-111. Available online: http:/ / mit.imt.si/izvodi/mit141/golja.pdf (accessed on 19 August 2021).

35. Lin, M.; Yang, Y.; Xi, P.; Chen, S.L. Microencapsulation of Water-Soluble Flame Retardant Containing Organophosphorus and its Application on Fabric. J. Appl. Polym. Sci. 2006, 102, 4915-4920. [CrossRef]

36. Giraud, S.; Bourbigot, S.; Rochery, M.; Vroman, I.; Tighzert, L.; Delobel, R.; Poutch, F. Flame Retarded Polyurea with Microencapsulated Ammonium Phosphate for Textile Coating. Polym. Degrad. Stab. 2005, 88, 106-113. [CrossRef]

37. Li, J.; Zhu, X.; Wang, H.; Lin, P.; Jia, L.; Li, L.; Chen, Y. Synthesis and Properties of Multifunctional Microencapsulated Phase Change Material for Intelligent Textiles. J. Mater. Sci. 2021, 56, 2176-2191. [CrossRef]

38. Larciprete, M.C.; Paoloni, S.; Cesarini, G.; Sibilia, C.; Rubežienè, V.; Sankauskaitè, A. Thermo-Regulating Properties of Textiles with Incorporated Microencapsulated Phase Change Materials. MRS Adv. 2020, 5, 1023-1028. [CrossRef]

39. Skurkytè-Papievienè, V.; Abraitienè, A.; Sankauskaitè, A.; Rubežienè, V.; Dubinskaitè, K. Enhancement of Thermal Properties of Bio-Based Microcapsules Intended for Textile Applications. Open Chem. 2020, 18, 669-680. [CrossRef]

40. Zhang, G.; Cai, C.; Wang, Y.; Liu, G.; Zhou, L.; Yao, J.; Zhu, G. Preparation and Evaluation of Thermo-Regulating Bamboo Fabric Treated by Microencapsulated Phase Change Materials. Text. Res. J. 2019, 89, 3387-3393. [CrossRef]

41. Chen, X.; Wu, B.; Fan, Y.; Duan, X.; Yang, M. Temperature Adjusting Performance of Thermoregulated Woven Fabric Finished with Phase-Change Microcapsule in Low-Temperature Environment. J. Eng. Fibers Fabr. 2019, 14, 1-10. [CrossRef]

42. Saraç, E.G.; Öner, E.; Kahraman, M.V. Microencapsulated Organic Coconut Oil as a Natural Phase Change Material for ThermoRegulating Cellulosic Fabrics. Cellulose 2019, 26, 8939-8950. [CrossRef]

43. Geng, X.; Li, W.; Wang, Y.; Lu, J.; Wang, J.; Wang, N.; Li, X.; Zhang, X. Reversible Thermochromic Microencapsulated Phase Change Materials for Thermal Energy Storage Application in Thermal Protective Clothing. Appl. Energy 2018, 217, $281-294$. [CrossRef]

44. Benmoussa, D.; Molnar, K.; Hannache, H.; Cherkaoui, O. Development of Thermo-Regulating Fabric Using Microcapsules of Phase Change Material. Mol. Cryst. Liq. Cryst. 2016, 627, 163-169. [CrossRef]

45. Keyan, K.; Ramachandran, T.; Shamugasundaram, O.L.; Balasubramaniam, M.; Ragavendra, T. Microencapsulation of PCMs in Textiles: A Review. J. Text. Appar. Technol. Manag. 2012, 7, 1-10. Available online: https://ojs.cnr.ncsu.edu/index.php/JTATM/ article/viewFile/2414/1412 (accessed on 20 August 2021).

46. Salaün, F.; Devaux, E.; Bourbigot, S.; Rumeau, P. Thermoregulating Response of Cotton Fabric Containing Microencapsulated Phase Change Materials. Thermochim. Acta 2010, 506, 82-93. [CrossRef]

47. Hu, L.; Li, X.; Ding, L.; Chen, L.; Zhu, X.; Mao, Z.; Feng, X.; Sui, X.; Wang, B. Flexible Textiles with Polypyrrole Deposited Phase Change Microcapsules for Efficient Photothermal Energy Conversion and Storage. Sol. Energy Mater. Sol. Cells 2021, $224,110985$. [CrossRef]

48. Geng, X.; Gao, Y.; Wang, N.; Han, N.; Zhang, X.; Li, W. Intelligent Adjustment of Light-to-Thermal Energy Conversion Efficiency of Thermo-Regulated Fabric Containing Reversible Thermochromic MicroPCMs. Chem. Eng. J. 2021, 408, 127276. [CrossRef]

49. Tong, W.; Tong, A. Solar-Absorbing Metamaterial Microencapsulation of Phase Change Materials for Thermo-Regulating Textiles. Int. J. Smart Nano Mater. 2015, 6, 105-112. [CrossRef]

50. Pargai, D.; Jahan, S. Application of Vitis vinifera Microcapsules on Cotton Fabric: A Potential to Prevent UV-Induced Skin Problems. J. Nat. Fibers 2020, 17, 412-426. [CrossRef]

51. Geethadevi, R.; Maheshwari, V. Long-lasting UV Protection and Mosquito Repellent Finish on Bamboo/Tencel Blended Fabric with Microencapsulated Essential Oil. Indian J. Fibre Text. Res. 2015, 40, 175-179. Available online: http://op.niscair.res.in/index. php/IJFTR/article/view/4631/309 (accessed on 23 August 2021).

52. Hong, S.A.; Kim, I.Y.; Kim, H.R.; Song, W.S. Manufacture of UV Absorbers and UV Protection Fabrics Using Microcapsules. Fibers Polym. 2011, 12, 491-498. [CrossRef]

53. Atiénzar-Navarro, R.; Bonet-Aracil, M.A.R.I.L.É.S.; Gisbert-Payá, J.; del Rey, R.; Picó, R. Sound Absorption of Textile Fabrics Doped with Microcapsules. Appl. Acoust. 2020, 164, 107285. [CrossRef]

54. Wang, W.; Liang, Y.; Yang, Z.; Zhang, W.; Wang, S. Construction of Ultraviolet Protection, Thermal Insulation, Superhydrophobic and Aromatic Textile with Al-Doped ZnO-Embedded Lemon Microcapsule Coatings. Text. Res. J. 2019, 89, 3860-3870. [CrossRef]

55. He, Z.; Bao, B.; Fan, J.; Wang, W.; Yu, D. Photochromic Cotton Fabric Based on Microcapsule Technology with Anti-Fouling Properties. Colloids Surf. A Physicochem. Eng. Asp. 2020, 594, 124661. [CrossRef] 
56. Khattab, T.A.; Fouda, M.M.; Abdelrahman, M.S.; Othman, S.I.; Bin-Jumah, M.; Alqaraawi, M.A.; Al Fassam, H.; Allam, A.A. Co-Encapsulation of Enzyme and Tricyanofuran Hydrazone into Alginate Microcapsules Incorporated onto Cotton Fabric as a Biosensor for Colorimetric Recognition of Urea. React. Funct. Polym. 2019, 142, 199-206. [CrossRef]

57. Hassan, M.M.; Sunderland, M. Antimicrobial and Insect-Resist Wool Fabrics by Coating with Microencapsulated Antimicrobial and Insect-Resist Agents. Prog. Org. Coat. 2015, 85, 221-229. [CrossRef]

58. Kim, J.R. Eucalyptus Oil-Loaded Microcapsules Grafted to Cotton Fabrics for Acaricidal Effect against Dermatophagoides farinae. J. Microencapsul. 2017, 34, 262-269. [CrossRef] [PubMed]

59. Eyupoglu, S.; Kut, D.; Girisgin, A.O.; Eyupoglu, C.; Ozuicli, M.; Dayioglu, H.; Civan, M.; Aydin, L. Investigation of the Bee-Repellent Properties of Cotton Fabrics Treated with Microencapsulated Essential Oils. Tex. Res. J. 2019, 89, $1417-1435$. [CrossRef]

60. Miro Specos, M.M.; García, J.J.; Tornesello, J.; Marino, P.; Vecchia, M.D.; Tesoriero, M.D.; Hermida, L.G. Microencapsulated Citronella Oil for Mosquito Repellent Finishing of Cotton Textiles. Trans. R. Soc. Trop. Med. Hyg. 2010, 104, 653-658. [CrossRef] [PubMed]

61. Miro Specos, M.M.; Garcia, J.J.; Gutierrez, A.C.; Hermida, L.G. Application of Microencapsulated Biopesticides to Improve Repellent Finishing of Cotton Fabrics. J. Text. Inst. 2017, 108, 1454-1460. [CrossRef]

62. Yao, T.T.; Wang, L.K.; Cheng, J.L.; Hu, Y.Z.; Zhao, J.H.; Zhu, G.N. Optimization of Pyrethroid and Repellent on Fabrics against Stegomyia albopicta (= Aedes albopictus) Using a Microencapsulation Technique. Med. Vet. Entomol. 2015, 29, 37-43. [CrossRef]

63. Mertgenç, C.; Enginar, H.; Yılmaz, H. Microencapsulation of Fragrance with Polyurethane-Urea and Application on Different Fabrics. Iran. J. Sci. Technol. Trans. A Sci. 2021, 45, 1-11. [CrossRef]

64. Wang, S.; Zhang, W.; Chen, Y.; Zhang, S.; Wang, W. The Aromatic Properties of Polyurea-Encapsulated Lavender Oil Microcapsule and their Application in Cotton Fabrics. J. Nanosci. Nanotechnol. 2019, 19, 4147-4153. [CrossRef] [PubMed]

65. Silva, M.; Martins, I.M.; Barreiro, M.F.; Dias, M.M.; Rodrigues, A.E. Functionalized Textiles with PUU/Limonene Microcapsules: Effect of Finishing Methods on Fragrance Release. J. Text. Inst. 2017, 108, 361-367. [CrossRef]

66. Zhao, D.; Jiao, X.; Zhang, M.; Ye, K.; Shi, X.; Lu, X.; Shea, K.J. Preparation of High Encapsulation Efficiency Fragrance Microcapsules and Their Application in Textiles. RSC Adv. 2016, 6, 80924-80933. [CrossRef]

67. He, Y.; Bowen, J.; Andrews, J.W.; Liu, M.; Smets, J.; Zhang, Z. Adhesion of Perfume-Filled Microcapsules to Model Fabric Surfaces. J. Microencapsul. 2014, 31, 430-439. [CrossRef]

68. Mercadé-Prieto, R.; Pan, X.; Fernández-González, A.; Zhang, Z.; Bakalis, S. Quantification of Microcapsules Deposited in Cotton Fabrics Before and After Abrasion Using Fluorescence Microscopy. Ind. Eng. Chem. Res. 2012, 51, 16741-16749. [CrossRef]

69. Ghayempour, S.; Montazer, M. Micro/Nanoencapsulation of Essential Oils and Fragrances: Focus on Perfumed, Antimicrobial, Mosquito-Repellent and Medical Textiles. J. Microencapsul. 2016, 33, 497-510. [CrossRef]

70. Bouaziz, A.; Dridi, D.; Gargoubi, S.; Zouari, A.; Majdoub, H.; Boudokhane, C.; Bartegi, A. Study on the Grafting of ChitosanEssential Oil Microcapsules onto Cellulosic Fibers to Obtain Bio Functional Material. Coatings 2021, 11, 637. [CrossRef]

71. Julaeha, E.; Puspita, S.; Eddy, D.R.; Wahyudi, T.; Nurzaman, M.; Nugraha, J.; Herlina, T.; Al Anshori, J. Microencapsulation of Lime (Citrus aurantifolia) Oil for Antibacterial Finishing of Cotton Fabric. RSC Adv. 2021, 11, 1743-1749. [CrossRef]

72. Beşen, B.S. Tea Tree Oil/Ethyl Cellulose Microcapsule Loaded Antimicrobial Textiles. AATCC J. Res. 2020, 7, 1-6. [CrossRef]

73. Sharkawy, A.; Fernandes, I.P.; Barreiro, M.F.; Rodrigues, A.E.; Shoeib, T. Aroma-Loaded Microcapsules with Antibacterial Activity for Eco-Friendly Textile Application: Synthesis, Characterization, Release, and Green Grafting. Ind. Eng. Chem. Res. 2017, 56, 5516-5526. [CrossRef]

74. Panisello, C.; Peña, B.; Gilabert Oriol, G.; Constantí, M.; Gumí, T.; Garcia-Valls, R. Polysulfone/Vanillin Microcapsules for Antibacterial and Aromatic Finishing of Fabrics. Ind. Eng. Chem. Res. 2013, 52, 9995-10003. [CrossRef]

75. Ocepek, B.; Boh, B.; Šumiga, B.; Forte Tavčer, P. Printing of Antimicrobial Microcapsules on Textiles. Color. Technol. 2012, 128, 95-102. [CrossRef]

76. Jo, Y.K.; Heo, S.J.; Peredo, A.P.; Mauck, R.L.; Dodge, G.R.; Lee, D. Stretch-Responsive Adhesive Microcapsules for StrainRegulated Antibiotic Release from Fabric Wound Dressings. Biomater. Sci. 2021, 9, 5136-5143. [CrossRef]

77. Mendes, S.; Catarino, A.; Zille, A.; Fernandes, N.; Bezerra, F.M. Vehiculation of Methyl Salicylate from Microcapsules Supported on Textile Matrix. Materials 2021, 14, 1087. [CrossRef]

78. Volmajer Valh, J.; Peršin, Z.; Vončina, B.; Vrezner, K.; Tušek, L.; Fras Zemljič, L. Microencapsulation of Cannabidiol in Liposomes as Coating for Cellulose for Potential Advanced Sanitary Material. Coatings 2021, 11, 3. [CrossRef]

79. Beşen, B.S.; Balcı, O.; Güneşoğlu, C.; Orhan, M.; Somuncuoğlu, E.İ.; Tatlı, İ.̇. Obtaining Medical Textiles Including Microcapsules of the Ozonated Vegetable Oils. Fibers Polym. 2017, 18, 1079-1090. [CrossRef]

80. Wijesirigunawardana, P.B.; Perera, B.G.K. Development of a Cotton Smart Textile with Medicinal Properties Using Lime Oil Microcapsules. Acta Chim. Slov. 2018, 65, 150-159. [CrossRef]

81. Massella, D.; Giraud, S.; Guan, J.; Ferri, A.; Salaün, F. Textiles for Health: A Review of Textile Fabrics Treated with Chitosan Microcapsules. Environ. Chem. Lett. 2019, 17, 1787-1800. [CrossRef]

82. Ripoll, L.; Bordes, C.; Etheve, S.; Elaissari, A.; Fessi, H. Cosmeto-Textile from Formulation to Characterization: An Overview. e-Polymers 2010, 10, 040. [CrossRef]

83. Stan, M.S.; Chirila, L.; Popescu, A.; Radulescu, D.M.; Radulescu, D.E.; Dinischiotu, A. Essential oil microcapsules immobilized on textiles and certain induced effects. Materials 2019, 12, 2029. [CrossRef] 
84. Azizi, N.; Chevalier, Y.; Majdoub, M. Isosorbide-Based Microcapsules for Cosmeto-Textiles. Ind. Crops Prod. 2014, 52, 150-157. [CrossRef]

85. Cheng, S.Y.; Yuen, M.C.W.; Kan, C.W.; Cheuk, K.K.L.; Chui, C.H.; Lam, K.H. Cosmetic Textiles with Biological Benefits: Gelatin Microcapsules Containing Vitamin C. Int. J. Mol. Med. 2009, 24, 411-419. [CrossRef]

86. Xu, C.; Hu, J.; Chen, Y.; Yang, Q.; Zhang, Y.; Wang, C.; Chen, K. Rapid Synthesis of Strawberry Microcapsules via Pickering Emulsion Photopolymerization for use in Multifunctional Fabric Coatings. Prog. Org. Coat. 2021, 152, 106110. [CrossRef]

87. Singh, N.; Sheikh, J. Multifunctional Linen Fabric Obtained through Finishing with Chitosan-Gelatin Microcapsules Loaded with Cinnamon Oil. J. Nat. Fibers 2021, 1-11. [CrossRef]

88. Chen, K.; Zhou, J.; Hu, J.; Zhang, J.; Heng, T.; Xu, C.; Yu, K. Preparation of pH-Responsive Dual-Compartmental Microcapsules via Pickering Emulsion and Their Application in Multifunctional Textiles. ACS Appl. Mater. Interfaces 2020, 13, 1234-1244. [CrossRef] [PubMed]

89. Chen, K.; Xu, C.; Zhou, J.; Zhao, R.; Gao, Q.; Wang, C. Multifunctional Fabric Coatings with Slow-Releasing Fragrance and UV Resistant Properties from Ethyl Cellulose/Silica Hybrid Microcapsules. Carbohydr. Polym. 2020, 232, 115821. [CrossRef]

90. Valle, J.A.B.; Valle, R.D.C.S.C.; Bierhalz, A.C.K.; Bezerra, F.M.; Hernandez, A.L.; Lis Arias, M.J. Chitosan Microcapsules: Methods of The Production and Use in the Textile Finishing. J. Appl. Polym. Sci. 2021, 138, 50482. [CrossRef]

91. Bah, M.G.; Bilal, H.M.; Wang, J. Fabrication and Application of Complex Microcapsules: A Review. Soft Matter 2020, 16, 570-590. [CrossRef]

92. Ozkan, G.; Franco, P.; De Marco, I.; Xiao, J.; Capanoglu, E. A Review of Microencapsulation Methods for food Antioxidants: Principles, Advantages, Drawbacks and Applications. Food Chem. 2019, 272, 494-506. [CrossRef] [PubMed]

93. Suganya, V.; Anuradha, V. Microencapsulation and Nanoencapsulation: A Review. Int. J. Pharm. Clin. Res 2017, 9, 233-239. [CrossRef]

94. Kaushik, P.; Dowling, K.; Barrow, C.J.; Adhikari, B. Microencapsulation of Omega-3 Fatty Acids: A Review of Microencapsulation and Characterization Methods. J. Funct. Foods 2015, 19, 868-881. [CrossRef]

95. Jamekhorshid, A.; Sadrameli, S.M.; Farid, M. A Review of Microencapsulation Methods of Phase Change Materials (PCMs) as a Thermal Energy Storage (TES) Medium. Renew. Sustain. Energy Rev. 2014, 31, 531-542. [CrossRef]

96. Golja, B.; Tavčer, P.F. Textile Functionalisation by Printing Fragrant, Antimicrobial and Flame-Retardant Microcapsules. Tekstilec 2016, 59, 278-288. [CrossRef]

97. Erkan, G.; Sariişik, M.; Pazarlioğlu, N.K. The Microencapsulation of Terbinafine via In Situ Polymerization of MelamineFormaldehyde and Their Application to Cotton Fabric. J. Appl. Polym. Sci. 2010, 118, 3707-3714. [CrossRef]

98. Palanikkumaran, M.; Gupta, K.K.; Agrawal, A.K.; Jassal, M. Highly Stable Hexamethylolmelamine Microcapsules Containing N-Octadecane Prepared by In Situ Encapsulation. J. Appl. Polym. Sci. 2009, 114, 2997-3002. [CrossRef]

99. Stanković Elesini, U.; Leskovšek, M.; Bernik, S.; Šumiga, B.; Urbas, R. Influence of Co-Current Spray Drying Conditions on Agglomeration of Melamine-Formaldehyde Microcapsules. Dry. Technol. 2016, 34, 1510-1520. [CrossRef]

100. Zhao, H.; Fei, X.; Cao, L.; Zhang, B.; Liu, X. Relation Between the Particle Size and Release Characteristics of Aromatic Melamine Microcapsules in Functional Textile Applications. RSC Adv. 2019, 9, 25225-25231. [CrossRef]

101. Stanković Elesini, U.; Švarc, J.; Šumiga, B.; Urbas, R. Melamine Formaldehyde Microcapsules with Fragrance Core Material: Preparation, Properties, and End Use. Text. Res. J. 2017, 87, 2435-2448. [CrossRef]

102. Golja, B.; Šumiga, B.; Forte Tavčer, P. Fragrant Finishing of Cotton with Microcapsules: Comparison between Printing and Impregnation. Color. Technol. 2013, 129, 338-346. [CrossRef]

103. Skurkyte-Papieviene, V.; Abraitiene, A.; Sankauskaite, A.; Rubeziene, V.; Baltusnikaite-Guzaitiene, J. Enhancement of the Thermal Performance of the Paraffin-Based Microcapsules Intended for Textile Applications. Polymers 2021, 13, 1120. [CrossRef]

104. Topbas, O.; Sariisik, A.M.; Erkan, G.; Ek, O. Photochromic Microcapsules by Coacervation and In Situ Polymerization Methods for Product-Marking Applications. Iran. Polym. J. 2020, 29, 117-132. [CrossRef]

105. Wang, S.; Ding, H.; Zhao, Y.; Li, Y.; Wang, W. Fabrication of Protective Textile with N-doped $\mathrm{TiO}_{2}$ Embedded Citral Microcapsule Coating and Its Air Purification Properties. Fibers Polym. 2020, 21, 334-342. [CrossRef]

106. Rodrigues, S.N.; Fernandes, I.; Martins, I.M.; Mata, V.G.; Barreiro, F.; Rodrigues, A.E. Microencapsulation of Limonene for Textile Application. Ind. Eng. Chem. Res. 2008, 47, 4142-4147. [CrossRef]

107. Azizi, N.; Abdelkader, M.B.; Chevalier, Y.; Majdoub, M. New $\beta$-Cyclodextrin-Based Microcapsules for Textiles Uses. Fibers Polym. 2019, 20, 683-689. [CrossRef]

108. Boh, B.; Šumiga, B. In Situ Polymerisation Microcapsules. Available online: https://bioencapsulation.net/group/300_literature/ 320_newsletters / Bioencap_innov_2013_03.pdf (accessed on 24 August 2021).

109. Šumiga, B.; Knez, E.; Vrtačnik, M.; Ferk Savec, V.; Starešinic, M.; Boh, B. Production of Melamine-Formaldehyde PCM Microcapsules with Ammonia Scavenger Used for Residual Formaldehyde Reduction. Acta Chim. Slov. 2011, 58, 14-25.

110. Alič, B.; Šebenik, U.; Krajnc, M. Differential Scanning Calorimetric Examination of Melamine-Formaldehyde Microcapsules Containing Decane. J. Appl. Polym. Sci. 2011, 119, 3687-3695. [CrossRef]

111. Yuan, H.; Li, G.; Yang, L.; Yan, X.; Yang, D. Development of Melamine-Formaldehyde Resin Microcapsules with Low Formaldehyde Emission Suited for Seed Treatment. Colloids Surf. B Biointerfaces 2015, 128, 149-154. [CrossRef] [PubMed]

112. Paiva, N.T.; Henriques, A.; Cruz, P.; Ferra, J.M.; Carvalho, L.H.; Magalhães, F.D. Production of Melamine Fortified UreaFormaldehyde Resins with Low Formaldehyde Emission. J. Appl. Polym. Sci. 2012, 124, 2311-2317. [CrossRef] 
113. Li, W.; Zhang, X.X.; Wang, X.C.; Niu, J.J. Preparation and Characterization of Microencapsulated Phase Change Material with Low Remnant Formaldehyde Content. Mater. Chem. Phys. 2007, 106, 437-442. [CrossRef]

114. Li, W.; Wang, J.; Wang, X.; Wu, S.; Zhang, X. Effects of Ammonium Chloride and Heat Treatment on Residual Formaldehyde Contents of Melamine-Formaldehyde Microcapsules. Colloid Polym. Sci. 2007, 285, 1691-1697. [CrossRef]

115. Perignon, C.; Ongmayeb, G.; Neufeld, R.; Frere, Y.; Poncelet, D. Microencapsulation by Interfacial Polymerisation: Membrane Formation and Structure. J. Microencapsul. 2015, 32, 1-15. [CrossRef]

116. Fiedler, J.O.; Carmona, Ó.G.; Carmona, C.G.; Lis, M.J.; Plath, A.M.S.; Samulewski, R.B.; Bezerra, F.M. Application of Aloe vera Microcapsules in Cotton Nonwovens to Obtain Biofunctional Textiles. J. Text. Inst. 2019, 111, 68-74. [CrossRef]

117. Sharma, R.; Goel, A. Development of Insect Repellent Finish by a Simple Coacervation Microencapsulation Technique. Int. J. Cloth. Sci. Technol. 2018, 30, 152-158. [CrossRef]

118. Turan, N.Y.; Turker, E.; Insaatci, Ö. Microparticles Loaded with Propolis to Make Antibacterial Cotton. Cellulose 2021, 28, 4469-4483. [CrossRef]

119. Demirbağ, S.; Aksoy, S.A. Encapsulation of Phase Change Materials by Complex Coacervation to Improve Thermal Performances and Flame Retardant Properties of the Cotton Fabrics. Fibers Polym. 2016, 17, 408-417. [CrossRef]

120. Deveci, S.S.; Basal, G. Preparation of PCM Microcapsules by Complex Coacervation of Silk Fibroin and Chitosan. Colloid Polym. Sci. 2009, 287, 1455-1467. [CrossRef]

121. Xiao, Z.; Xu, W.; Ma, J.; Zhao, Y.; Niu, Y.; Kou, X.; Ke, Q. Double-Encapsulated Microcapsules for the Adsorption to Cotton Fabrics. Coatings 2021, 11, 426. [CrossRef]

122. Lis, M.J.; García Carmona, Ó.; García Carmona, C.; Maestá Bezerra, F. Inclusion Complexes of Citronella Oil with $\beta-C y c l o d e x t r i n$ for Controlled Release in Biofunctional Textiles. Polymers 2018, 10, 1324. [CrossRef] [PubMed]

123. Mihailiasa, M.; Caldera, F.; Li, J.; Peila, R.; Ferri, A.; Trotta, F. Preparation of Functionalized Cotton Fabrics by Means of Melatonin Loaded $\beta$-Cyclodextrin Nanosponges. Carbohydr. Polym. 2016, 142, 24-30. [CrossRef]

124. Timilsena, Y.P.; Akanbi, T.O.; Khalid, N.; Adhikari, B.; Barrow, C.J. Complex Coacervation: Principles, Mechanisms and Applications in Microencapsulation. Int. J. Biol. Macromol. 2019, 121, 1276-1286. [CrossRef]

125. Challa, R.; Ahuja, A.; Ali, J.; Khar, R.K. Cyclodextrins in Drug Delivery: An Updated Review. AAPS PharmSciTech 2005, 6, E329-E357. [CrossRef] [PubMed]

126. Wadhwa, G.; Kumar, S.; Chhabra, L.; Mahant, S.; Rao, R. Essential Oil-Cyclodextrin Complexes: An Updated Review. J. Incl. Phenom. Macrocycl. Chem. 2017, 89, 39-58. [CrossRef]

127. Marcillo-Parra, V.; Tupuna-Yerovi, D.S.; González, Z.; Ruales, J. Encapsulation of Bioactive Compounds from Fruit and Vegetable By-Products for Food Application-A Review. Trends Food Sci. Technol. 2021, 116, 11-23. [CrossRef]

128. Geranpour, M.; Assadpour, E.; Jafari, S.M. Recent Advances in the Spray Drying Encapsulation of Essential Fatty Acids and Functional Oils. Trends Food Sci. Technol. 2020, 102, 71-90. [CrossRef]

129. Carvalho, I.T.; Estevinho, B.N.; Santos, L. Application of Microencapsulated Essential Oils in Cosmetic and Personal Healthcare Products-A Review. Int. J. Cosmet. Sci. 2016, 38, 109-119. [CrossRef] [PubMed]

130. Yingngam, B.; Kacha, W.; Rungseevijitprapa, W.; Sudta, P.; Prasitpuriprecha, C.; Brantner, A. Response Surface Optimization of Spray-Dried Citronella Oil Microcapsules with Reduced Volatility and Irritation for Cosmetic Textile Uses. Powder Technol. 2019, 355, 372-385. [CrossRef]

131. Yang, Z.; Zeng, Z.; Xiao, Z.; Ji, H. Preparation and Controllable Release of Chitosan/Vanillin Microcapsules and their Application to Cotton Fabric. Flavour Fragr. J. 2014, 29, 114-120. [CrossRef]

132. Brlek, I.; Ludaš, A.; Sutlović, A. Synthesis and Spectrophotometric Analysis of Microcapsules Containing Immortelle Essential Oil. Molecules 2021, 26, 2390. [CrossRef] [PubMed]

133. Erkan, G.; Sarışık, M. Antifungal Microcapsules of Ethyl Cellulose by Solvent Evaporation and their Application to Cotton Fabric. Fibres Text. East. Eur. 2015, 23, 125-130. [CrossRef]

134. Salaün, F.; Devaux, E.; Bourbigot, S.; Rumeau, P. Application of Contact Angle Measurement to the Manufacture of Textiles Containing Microcapsules. Text. Res. J. 2009, 79, 1202-1212. [CrossRef]

135. López, A.; Lis, M.J.; Maesta Bezerra, F.; Vilaseca, M.; Vallés, B.; Prieto, R.; Simó, M. Production and Evaluation of Antimicrobial Microcapsules with Essential Oils Using Complex Coacervation. J. Biomed. Sci. Eng. 2019, 12, 377-390. [CrossRef]

136. Singh, N.; Sheikh, J. Sustainable Development of Mosquito-Repellent, Flame-Retardant, Antibacterial, Fragrant and Antioxidant Linen Using Microcapsules Containing Thymus Vulgaris Oil in In-Situ Generated Chitosan-Phosphate. Cellulose 2021, 28, 2599-2614. [CrossRef]

137. Bhatt, L.; Singh, S.S.J. Comparative Analysis of Lemongrass Oil Application on Textile Substate Through Microencapsulation and Exhaust Method. Int. J. Adv. Res. Sci. Eng. 2018, 7, 313-320.

138. Hui, P.C.; Wang, W.; Kan, C.; Ng, F.S.; Wat, E.; Zhang, V.X.; Chan, C.; Lau, C.B.; Leung, P. Microencapsulation of Traditional Chinese Herbs-Pentaherbs Extracts and Potential Application in Healthcare Textiles. Colloid Surface B Biointerfaces 2013, 111, 156-161. [CrossRef] [PubMed]

139. Abdelkader, M.B.; Azizi, N.; Baffoun, A.; Chevalier, Y.; Majdoub, M. New Microcapsules Based on Isosorbide for Cosmetotextile: Preparation And Characterization. Ind. Crops Prod. 2018, 123, 591-599. [CrossRef]

140. Salaün, F. Microencapsulation as An Effective Tool for the Design of Functional Textiles. In Advances in Textile Engineering; Trans Tech Publications Ltd.: Bäch, Switzerland, 2019. 
141. Abdelkader, M.B.; Azizi, N.; Baffoun, A.; Chevalier, Y.; Majdoub, M. Fragrant Microcapsules Based on $\beta$-Cyclodextrin For Cosmetotextile Application. J. Renew. Mater. 2019, 7, 1347-1362. [CrossRef]

142. Arias, M.J.L.; López, A.; Vilaseca, M.; Vallès, B.; Prieto, R.; Simó, M.; Valle, J.A.B.; Valle, R.D.C.S.C.; Bezerra, F.M.; Bellalta, J.P. Influence of Chitosan Characteristics in the Microencapsulation of Essential Oils. J. Biomed. Sci. Eng. 2021, 14, 119-129. [CrossRef]

143. Bezerra, F.M.; Lis, M.; García Carmona, O.; García Carmona, C.; Moisés, M.P.; Zanin, G.M.; Moraes, F.F. Assessment of the Delivery of Citronella Oil from Microcapsules Supported on Wool Fabrics. Powder Technol. 2019, 343, 775-782. [CrossRef]

144. Ferrándiz, M.; Capablanca, L.; García, D.; Bonet, M.A. Application of Antimicrobial Microcapsules on Agrotextiles. J. Agric. Chem. Environ. 2017, 6, 62-82. [CrossRef]

145. Khodary, M.M.M.; El-Rafie, H.M.; Abdel Salam, H.M.; El-Rafie, M.H. Imparting Eco-Friendly Antibacterial and Anti-Inflammatory Finishing by Microencapsulation Technique for Cotton Fabric. Int. Des. J. 2017, 7, 131-140. [CrossRef]

146. Soo, P.M. Method for Producing Coated Fabric Having Antibacterial Activity Removing Bad Smell and Giving Off Forest Fragrance and the Coated Fabric Produced by the Method. Korean Patent KR20020059050A, 12 July 2002.

147. Soo, P.M. Producing Method of Coated Fabric Changing Its Color According to Temperature Variation and Having Excellent Washing Resistance and the Coated Fabric Produced by the Method. Korean Patent KR20020059049A, 12 July 2002.

148. Zhao, H.; Fei, X.; Cao, L.; Zhang, B.; Liu, X. The Fabrication of Fragrance Microcapsules and Their Sustained and Broken Release Behavior. Materials 2019, 12, 393. [CrossRef] [PubMed]

149. Kert, M.; Krkoč, V.; Gorjanc, M. Influence of Optical Brightening Agent Concentration on Properties of Cotton Fabric Coated with Photochromic Microcapsules Using A Pad-Dry-Cure Process. Polymers 2019, 11, 1919. [CrossRef] [PubMed]

150. Sannapapamma, K.J.; Malligawad Lokanath, H.; Naikwadi, S. Antimicrobial and Aroma Finishing of Organic Cotton Knits Using Vetiver Oil Microcapsules for Health Care Textiles. Inter. J. Mater. Text. Eng. 2018, 12, 82-91. [CrossRef]

151. Yuqing, C.; Kuanjun, F.; Yawei, S. Colored Polymer Microsphere Ink for Inkjet. Printing. Patent CN105504990A, 20 April 2016.

152. Lam, P.L.; Li, L.; Yuen, C.W.M.; Gambari, R.; Wong, R.S.M.; Chui, C.H.; Lam, K.H. Effects of Multiple Washing on Cotton Fabrics Containing Berberine Microcapsules with Anti-Staphylococcus Aureus Activity. J. Microencapsul. 2013, 30, 143-150. [CrossRef] [PubMed]

153. Fei, B.; Xin, J.H. N, N-diethyl-m-toluamide-Containing Microcapsules for Bio-Cloth Finishing. Am. J. Trop. Med. Hyg. 2007, 77, 52-57. [CrossRef]

154. Stankovič Elesini, U.; Knez, E.; Leskovšek, M. Vgrajevanje Mikrokapsul v Tekstilna Vlakna. Tekstilec 2004, 47, 175-184.

155. Leskovšek, M.; Jedrinović, G.; Stankovič Elesini, U. Properties of Polypropylene Fibres with Incorporated Microcapsules. Acta Chim. Slov. 2004, 51, 699-715.

156. Gao, X.Y.; Han, N.; Zhang, X.X.; Yu, W.Y. Melt-Processable Acrylonitrile-Methyl Acrylate Copolymers and Melt-Spun Fibers Containing MicroPCMs. J. Mater. Sci. 2009, 44, 5877-5884. [CrossRef]

157. Zhang, X.X.; Wang, X.C.; Tao, X.M.; Yick, K.L. Energy Storage Polymer/MicroPCMs Blended Chips and Thermo-Regulated Fibers. J. Mater. Sci. 2005, 40, 3729-3734. [CrossRef]

158. Zhang, X.X.; Wang, X.C.; Tao, X.M.; Yick, K.L. Structures and Properties of Wet Spun Thermo-Regulated PolyacrylonitrileVinylidene Chloride Fibers. Text. Res. J. 2006, 76, 351-359. [CrossRef]

159. Kim, J.; Cho, G. Thermal Storage/Release, Durability, and Temperature Sensing Properties of Thermostatic Fabrics Treated with Octadecane-Containing Microcapsules. Text. Res. J. 2002, 72, 1093-1098. [CrossRef]

160. Koo, K.; Choe, J.; Park, Y. The Application of PCMMcs and SiC by Commercially Direct Dual-Complex Coating on Textile Polymer. Appl. Surf. Sci. 2009, 255, 8313-8318. [CrossRef]

161. Koo, K.; Park, Y.; Choe, J.; Kim, E. The Application of Microencapsulated Phase-Change Materials to Nylon Fabric Using Direct Dual Coating Method. J. Appl. Polym. Sci. 2008, 108, 2337-2344. [CrossRef]

162. Sanchez, P.; Sanchez-Fernandez, M.V.; Romero, A.; Rodriguez, J.F.; Sanchez-Silva, L. Development of Thermo-Regulating Textiles Using Paraffin Wax Microcapsules. Thermochim. Acta 2010, 498, 16-21. [CrossRef]

163. Sánchez-Silva, L.; Rodríguez, J.F.; Romero, A.; Sánchez, P. Preparation of Coated Thermo-Regulating Textiles Using RubithermRT31 Microcapsules. J. Appl. Polym. Sci. 2012, 124, 4809-4818. [CrossRef]

164. Pak, A.R.; Park, J.H.; Lee, S.G. Blowing Properties and Functionality of Thermoplastic Polyester Film Using Thermally Expandable Microcapsules. Polymers 2019, 11, 1652. [CrossRef] [PubMed]

165. Otake, Y.; Kobayashi, T.; Asabe, H.; Murakami, N.; Ono, K. Biodegradation of Low-Density Polyethylene, Polystyrene, Polyvinyl Chloride, and Urea Formaldehyde Resin Buried Under Soil for Over 32 Years. J. Appl. Polym. Sci. 1995, 56, 1789-1796. [CrossRef]

166. Danso, D.; Chow, J.; Streit, W.R. Plastics: Environmental and Biotechnological Perspectives on Microbial Degradation. Appl. Environ. Microbiol. 2019, 85, e01095-19. [CrossRef] [PubMed]

167. El-Sayed, W.S.; El-Baz, A.F.; Othman, A.M. Biodegradation of Melamine Formaldehyde by Micrococcus sp. Strain MF-1 Isolated from Aminoplastic Wastewater Effluent. Int. Biodeterior. Biodegrad. 2006, 57, 75-81. [CrossRef]

168. Nakajima-Kambe, T.; Shigeno-Akutsu, Y.; Nomura, N.; Onuma, F.; Nakahara, T. Microbial Degradation of Polyurethane, Polyester Polyurethanes and Polyether Polyurethanes. Appl. Microbiol. Biotechnol. 1999, 51, 134-140. [CrossRef]

169. Ibrahim, I.N.; Maraqa, A.; Hameed, K.M.; Saadoun, I.M.; Maswadeh, H.M. Assessment of Potential Plastic-Degrading Fungi in Jordanian Habitats. Turk. J. Biol. 2011, 35, 551-557. [CrossRef]

170. Khan, S.; Nadir, S.; Shah, Z.U.; Shah, A.A.; Karunarathna, S.C.; Xu, J.; Khan, A.; Munir, S.; Hasan, F. Biodegradation of Polyester Polyurethane by Aspergillus Tubingensis. Environ. Pollut. 2017, 225, 469-480. [CrossRef] 
171. Khan, S.; Nadir, S.; Dong, Y.; Schaefer, D.A.; Mortimer, P.E.; Gui, H.; Khan, A.; Yu, M.; Iqbal, S.; Sheng, J.; et al. Biodegradation of Polyester Polyurethane by Aspergillus Flavus G10. bioRxiv 2020. [CrossRef]

172. Brunner, I.; Fischer, M.; Rüthi, J.; Stierli, B.; Frey, B. Ability of Fungi Isolated from Plastic Debris Floating in the Shoreline of A Lake to Degrade Plastics. PLoS ONE 2018, 13, e0202047. [CrossRef]

173. Russell, J.R.; Huang, J.; Anand, P.; Kucera, K.; Sandoval, A.G.; Dantzler, K.W.; Hickman, D.; Jee, J.; Kimovec, F.M.; Koppstein, D.; et al. Biodegradation of Polyester Polyurethane by Endophytic Fungi. Appl. Environ. Microbiol. 2011, 77, 6076-6084. [CrossRef]

174. Deguchi, T.; Kakezawa, M.; Nishida, T. Nylon Biodegradation by Lignin-Degrading Fungi. Appl. Environ. Microbiol. 1997, 63, 329-331. [CrossRef] [PubMed]

175. Negoro, S. Biodegradation of Nylon Oligomers. Appl. Microbiol. Biotechnol. 2000, 54, 461-466. [CrossRef] [PubMed]

176. Sudhakar, M.; Priyadarshini, C.; Doble, M.; Murthy, P.S.; Venkatesan, R. Marine Bacteria Mediated Degradation of Nylon 66 and 6. Int. Biodeterior. Biodegr. 2007, 60, 144-151. [CrossRef]

177. Kim, D.Y.; Rhee, Y.H. Biodegradation of Microbial and Synthetic Polyesters by Fungi. Appl. Microbiol. Biotechnol. 2003, 61, 300-308. [CrossRef] [PubMed]

178. Müller, R.J.; Kleeberg, I.; Deckwer, W.D. Biodegradation of Polyesters Containing Aromatic Constituents. J. Biotechnol. 2001, 86, 87-95. [CrossRef]

179. Liu, J.; Willfor, S.; Xu, C. A Review of Bioactive Plant Polysaccharides: Biological Activities, Functionalization, and Biomedical Applications. Bioact. Carbohydr. Diet. Fibre 2015, 5, 31-41. [CrossRef]

180. Park, C.H.; Kang, Y.K.; Im, S.S.I. Biodegradability of Cellulose Fabrics. J. Appl. Polym. Sci. 2004, 94, 248-253. [CrossRef]

181. Yin, G.Z.; Yang, X.M. Biodegradable Polymers: A Cure for the Planet, But A Long Way to Go. J. Polym. Res. 2020, 27, 38. [CrossRef]

182. Amin, M.; Abadi, G.; Katas, H. Purification, Characterization and Comparative Studies of Spray-Dried Bacterial Cellulose Microparticles. Carbohydr. Polym. 2014, 99, 181-185. [CrossRef]

183. Gupta, B.S. Manufacture, Types and Properties of Biotextiles for Medical Applications. In Biotextiles as Medical Implants; Elsevier: Oxford, UK; Cambridge, UK; Philadelphia, PA, USA; New Delhi, India, 2013; pp. 3-47. [CrossRef]

184. Smith, S.; Ozturk, M.; Frey, M. Soil Biodegradation of Cotton Fabrics Treated with Common Finish. Cellulose 2021, 28, 4485-4494. [CrossRef]

185. Malis, D.; Jeršek, B.; Tomšič, B.; Štular, D.; Golja, B.; Kapun, G.; Simončič, B. Antibacterial Activity and Biodegradation of Cellulose Fiber Blends with Incorporated ZnO. Materials 2019, 12, 3399. [CrossRef]

186. Sülar, V.; Devrim, G. Biodegradation Behaviour of Different Textile Fibres: Visual, Morphological, Structural Properties and Soil Analyses. Fibres Text. East. Eur. 2019, 27, 100-111. [CrossRef]

187. Milošević, M.; Krkobabić, A.; Radoiči, M.; Šaponjić, Z.; Radetić, T.; Radetić, M. Biodegradation of Cotton and Cotton/Polyester Fabrics Impregnated with $\mathrm{Ag} / \mathrm{TiO}_{2}$ Nanoparticles in Soil. Carbohydr. Polym. 2017, 158, 77-84. [CrossRef]

188. Arshad, K.; Skrifvars, M.; Vivod, V.; Valh, J.; Voncina, B. Biodegradation of Natural Textile Materials in Soil. Tekstilec 2014, 57, 118-132. [CrossRef]

189. Klemenčič, D.; Simončič, B.; Tomšič, B.; Orel, B. Biodegradation of Silver Functionalised Cellulose Fibres. Carbohydr. Polym. 2010, 80, 426-435. [CrossRef]

190. Tomšič, B.; Simončič, B.; Orel, B.; Vilčnik, A.; Spreizer, H. Biodegradability of Cellulose Fabric Modified by Imidazolidinone. Carbohydr. Polym. 2007, 69, 478-488. [CrossRef]

191. Salerno-Kochan, R.; Szostak-Kotowa, J. Biodegradation of Cellulose Textiles. Fibres Text. East. Eur. 2001, 9, 69-72.

192. Dridi, D.; Bouaziz, A.; Gargoubi, S.; Zouari, A.; B'chir, F.; Bartegi, A.; Majdoub, H.; Boudokhane, C. Enhanced Antibacterial Efficiency of Cellulosic Fibers: Microencapsulation and Green Grafting Strategies. Coatings 2021, 11, 980. [CrossRef]

193. Gaytán, I.; Burelo, M.; Loza-Tavera, H. Current Status on the Biodegradability of Acrylic Polymers: Microorganisms, Enzymes and Metabolic Pathways Involved. Appl. Microbiol. Biotechnol. 2021, 105, 991-1006. [CrossRef] [PubMed]

194. Xiao, Y.; WU, B.; Fu, X.; Wang, R.; Lei, J. Preparation of Biodegradable Microcapsules Through and Organic Solvent-Free Interfacial Polymerization Method. Polym. Adv. Technol. 2019, 30, 483-488. [CrossRef]

195. de Carvalho Arjona, J.; das Graças Silva-Valenzuela, M.; Wang, S.H.; Valenzuela-Diaz, F.R. Biodegradable Nanocomposite Microcapsules for Controlled Release of Urea. Polymers 2021, 13, 722. [CrossRef] [PubMed]

196. Jia, Y.; Fei, J.; Cui, Y.; Yang, Y.; Gao, L.; Li, J. pH-Responsive Polysaccharide Microcapsules Through Covalent Bonding Assembly. Chem. Commun. 2011, 47, 1175-1177. [CrossRef]

197. Maesta Bezerra, F.; Carmona, O.C.; Carmona, C.G.; Lis, M.J.; de Moraes, F.F. Controlled Release of Microencapsulated Citronella Essential Oil on Cotton and Polyester Matrices. Cellulose 2016, 23, 1459-1470. [CrossRef]

198. Ryu, S.J.; Bae, H.S. Properties Analysis of Crosslinked Chitosan Microcapsules by Multiple Emulsification Method. Fash. Text. 2021, 8, 9. [CrossRef]

199. Liu, X.; Lou, Y. Preparation of Microencapsulated Phase Change Materials by the Sol-Gel Process and Its Application on Textiles. Fibres Text. East. Eur. 2015, 23, 63-67.

200. Microcapsule Market. Available online: https://www.marketsandmarkets.com/Market-Reports/microcapsule-market-24415649 .html?gclid=EAIaIQobChMI4dvb-4ra8wIVXUaRBR0srQuhEAAYASAAEgLwsfD_BwE (accessed on 21 October 2021). 
201. Meticulous Market Research. Available online: https://www.globenewswire.com/news-release/2021/06/24/2252620/0 /en/Microencapsulation-Market-Worth-17-31-billion-by-2027-Growing-at-a-CAGR-of-11-7-from-2020-Exclusive-Report-byMeticulous-Research.html (accessed on 21 October 2021).

202. Deng, H.; Wei, R.; Luo, W.; Hu, L.; Li, B.; Shi, H. Microplastic Pollution in Water and Sediment in a Textile Industrial Area. Environ. Pollut. 2020, 258, 113658. [CrossRef]

203. Acharya, S.; Rumi, S.S.; Hu, Y.; Abidi, N. Microfibers from Synthetic Textiles as A Major Source of Microplastics in the Environment: A review. Text. Res. J. 2021, 91, 2136-2156. [CrossRef]

204. Patti, A.; Cicala, G.; Acierno, D. Eco-Sustainability of the Textile Production: Waste Recoveryand Current Recycling in The Composites World. Polymers 2021, 13, 134. [CrossRef] [PubMed]

205. Kumar, D.; Bhardwaj, R.; Jassal, S.; Goyal, T.; Khullar, A.; Gupta, N. Application of Enzymes for An Eco-Friendly Approach To Textile Processing. Environ. Sci. Pollut. Res. 2021, 1-11. [CrossRef]

206. Hashem, M.; El-Bisi, M.; Sharaf, S.; Refaie, R. Pre-Cationization of Cotton Fabrics: An Effective Alternative Tool for Activation of Hydrogen Peroxide Bleaching Process. Carbohyd. Polym. 2010, 79, 533-540. [CrossRef]

207. Kert, M.; Forte Tavčer, P.; Hladnik, A.; Spasić, K.; Puač, N.; Petrović, Z.L.; Gorjanc, M. Application of Fragrance Microcapsules onto Cotton Fabric after Treatment with Oxygen and Nitrogen Plasma. Coatings 2021, 11, 1181. [CrossRef]

208. Ashraf, M.A.; Khan, A.M.; Ahmad, M.; Sarfraz, M. Effectiveness of Silica Based Sol-Gel Microencapsulation Method for Odorants and Flavors Leading to Sustainable Environment. Front. Chem. 2015, 3, 42. [CrossRef] [PubMed] 